\title{
Article \\ Amyloid Beta-Mediated Changes in Synaptic Function and Spine Number of Neocortical Neurons Depend on NMDA Receptors
}

\author{
Michaela K. Back, Sonia Ruggieri, Eric Jacobi and Jakob von Engelhardt *(D)
}

check for

updates

Citation: Back, M.K.; Ruggieri, S.; Jacobi, E.; von Engelhardt, J. Amyloid Beta-Mediated Changes in Synaptic Function and Spine Number of Neocortical Neurons Depend on NMDA Receptors. Int. J. Mol. Sci. 2021, 22, 6298. https://doi.org/ $10.3390 /$ ijms 22126298

Academic Editor: Arkadiusz Orzechowski

Received: 4 May 2021

Accepted: 9 June 2021

Published: 11 June 2021

Publisher's Note: MDPI stays neutral with regard to jurisdictional claims in published maps and institutional affiliations.

Copyright: (c) 2021 by the authors. Licensee MDPI, Basel, Switzerland. This article is an open access article distributed under the terms and conditions of the Creative Commons Attribution (CC BY) license (https:// creativecommons.org/licenses/by/ $4.0 /)$.
Institute of Pathophysiology, Focus Program Translational Neuroscience (FTN), University Medical Center of the Johannes Gutenberg, University Mainz, 55128 Mainz, Germany; michaela.back@uni-mainz.de (M.K.B.); rugsonia@uni-mainz.de (S.R.); eric.jacobi@uni-mainz.de (E.J.)

* Correspondence: engelhardt@uni-mainz.de

Abstract: Onset and progression of Alzheimer's disease (AD) pathophysiology differs between brain regions. The neocortex, for example, is a brain region that is affected very early during AD. NMDA receptors (NMDARs) are involved in mediating amyloid beta $(A \beta)$ toxicity. NMDAR expression, on the other hand, can be affected by $\mathrm{A} \beta$. We tested whether the high vulnerability of neocortical neurons for A $\beta$-toxicity may result from specific NMDAR expression profiles or from a particular regulation of NMDAR expression by A $\beta$. Electrophysiological analyses suggested that pyramidal cells of 6-monthsold wildtype mice express mostly GluN1/GluN2A NMDARs. While synaptic NMDAR-mediated currents are unaltered in 5xFAD mice, extrasynaptic NMDARs seem to contain GluN1/GluN2A and GluN1/GluN2A/GluN2B. We used conditional GluN1 and GluN2B knockout mice to investigate whether NMDARs contribute to A $\beta$-toxicity. Spine number was decreased in pyramidal cells of $5 x F A D$ mice and increased in neurons with 3-week virus-mediated $A \beta$-overexpression. NMDARs were required for both $A \beta$-mediated changes in spine number and functional synapses. Thus, our study gives novel insights into the $A \beta$-mediated regulation of NMDAR expression and the role of NMDARs in $A \beta$ pathophysiology in the somatosensory cortex.

Keywords: Alzheimer's disease; 5xFAD; Amyloid beta; NMDAR; somatosensory cortex

\section{Introduction}

Alzheimer's disease (AD) is a neurodegenerative disease defined by the occurrence of amyloid beta $(\mathrm{A} \beta)$ plaques and tau tangles in the brain. Cognitive impairment, an early symptom in $\mathrm{AD}$, occurs already before $\mathrm{A} \beta$ plaques start to build up. In line with this, AD progression correlates better with the amount of soluble $A \beta$ than with the number of $\mathrm{A} \beta$ plaques [1]. Interestingly, load of soluble $\mathrm{A} \beta, \mathrm{A} \beta$ plaques, and tangle formation vary strongly between brain areas in mouse models and human patients [2,3]. Although memory deficits occur as early symptoms in AD patients, $\mathrm{A} \beta$ plaques occur in the hippocampus, a brain area involved in memory formation, later than in the neocortex [3-6]. In line with these findings from AD patients, the 5xFAD AD mouse model shows spine loss and neuron loss in the neocortex earlier than in the hippocampus [7]. However, the reason for the region-specific differences in A $\beta$-toxicity is not known.

Memantine, an open-channel blocker of $N$-methyl-D-aspartate receptors (NMDARs) improves cognitive abilities in moderate-to-severe $\mathrm{AD}[8,9]$. In addition, several studies had suggested that NMDARs play a role in A $\beta$-toxicity in rodent AD models [10-13]. However, the contribution of NMDARs to A $\beta$-toxicity differs strongly between studies. Thus, NMDAR activation is required for $A \beta$-mediated spine loss in cultured neurons $[12,14-16]$ and brain slices [17-21] of AD model mice. In contrast, we and others found that NMDARs are dispensable for the $A \beta$-mediated reduction in spine number of hippocampal neurons in adult mice. Developmental changes and region-specific differences in expression of 
NMDAR subtypes may account for the diverse roles of NMDARs in A $\beta$-toxicity and may be the reason for brain region-specific differences in susceptibility to $A \beta$-toxicity. Thus, different NMDAR subunits regulate spine formation and stability in the developing and adult mouse brain [22]. Especially, the GluN2 subunits are key factors during development, such that incorporation of GluN2A stabilizes synapses and GluN2B destabilizes synapses, allowing the formation or retraction of spines [22].

NMDARs are composed of four subunits, of which two are GluN1 subunits and two are combinations of GluN2(A-D) or GluN3(A or B) subunits $[23,24]$. Neurons of the developing forebrain express predominantly GluN1 and GluN2B subunits and much less GluN2A, GluN2C, and GluN2D [25-29]. The GluN2A subunits are upregulated with development such that diheteromeric GluN1/GluN2A, GluN1/GluN2B, and triheteromeric GluN1/GluN2A/GluN2B-containing NMDARs are the most abundant forms in the adult forebrain $[30,31]$. The expression of NMDARs with different subunit compositions results in diverse NMDAR functions [32]. For example, GluN1/GluN2B-containing NMDARs display considerably slower decay kinetics than GluN1/GluN2A-containing NMDARs [33]. This explains why overactivation of GluN1/GluN2B-containing NMDARs induces a stronger $\mathrm{Ca}^{2+}$-mediated excitotoxicity than the overactivation of GluN1/GluN2A-containing NMDARs [34]. Differential expression [35] or regulation [36,37] of the subunits GluN2A and GluN2B might therefore account for brain region-specific susceptibility to A $\beta$-toxicity.

The mechanisms of how NMDARs contribute to $A \beta$-toxicity are complex and still not completely understood. A $\beta$ may influence NMDAR activation/function by directly interacting with the channels [38], by augmenting ambient glutamate levels [39,40], or by influencing NMDAR subunit expression and subcellular localization [11,12,41]. Redistribution of NMDAR expression on the cell surface may contribute to toxicity as shown for other neurodegenerative diseases [42], because the activation of synaptic NMDARs stimulates pro-survival signaling, whereas the activation of extrasynaptic NMDARs induces neuron apoptosis [43,44] (but see also: [45]).

To test whether specific expression and/or regulation of NMDAR subunits contribute to the early neuronal A $\beta$-toxicity in the neocortex, we investigated NMDAR-mediated currents in neocortical neurons with virus-mediated $A \beta$-overexpression as well as in neocortical neurons of the 5xFAD mouse model. In contrast to the previously observed downregulation of NMDARs in hippocampal neurons [12,46], we observed little change in the amplitude of synaptic and extrasynaptic NMDAR-mediated currents in neocortical neurons of 5xFAD mice. However, we found changes in the decay and deactivation kinetics consistent with an upregulation of extrasynaptic GluN2B-containing NMDARs. The contribution of NMDARs to $A \beta$-toxicity in adult neocortical neurons was investigated using conditional knockout of GluN1, GluN2A, or GluN2B. Three weeks of A $\beta$-overexpression reduced the number of functional synapses and increased the number of spines. In contrast, spine number was reduced in neocortical neurons of 6-months-old 5xFAD mice. The $A \beta$-mediated change in spine number depended on the presence of NMDARs. Finally, deletion of NMDARs per se reduced spine number. Thus, our study gives novel insights into the regulation and role of NMDARs in AD pathophysiology.

\section{Results}

\subsection{5xFAD Mice Show a High Intracellular A $\beta$ Burden and $A \beta$ Plaques in the Somatosensory Cortex}

To investigate $\mathrm{A} \beta$-toxicity in the cortex, we used the $5 x \mathrm{FAD}$ mouse model. This wellestablished mouse model shows early and aggressive A $\beta$ accumulation [47]. Previously, we had observed that the number of synapses and spines were reduced in dentate gyrus granule cells of 5xFAD mice at an age of 12-months, but unaltered in 6-months-old 5xFAD mice [46]. Given that $A \beta$-expression, onset, and severity of $A \beta$-pathology differs between brain regions with early onset and severity in the cortex of $5 x F A D$ mice $[7,47]$, we investigated whether signs of $A \beta$-overexpression can be observed in the somatosensory cortex of 6-months-old 5xFAD mice. A $\beta$ immunofluorescence staining using the 6E10 antibody showed strong $A \beta$ signals in the somatosensory cortex of $5 x F A D$ mice (Figure 1). This 
antibody detects amino acid residues $1-16$ of the $A \beta$ protein. Thus, it can be used to stain soluble forms of $A \beta$ as well as $A \beta$ plaques. The $A \beta$-staining was found mainly intracellularly in neurons of the somatosensory cortex of 6-months-old 5xFAD mice accompanied by a smaller amount of extracellular $A \beta$ plaques (Figure 1). No $A \beta$ staining was observed in aged-matched wildtype (WT) mice (Figure 1).

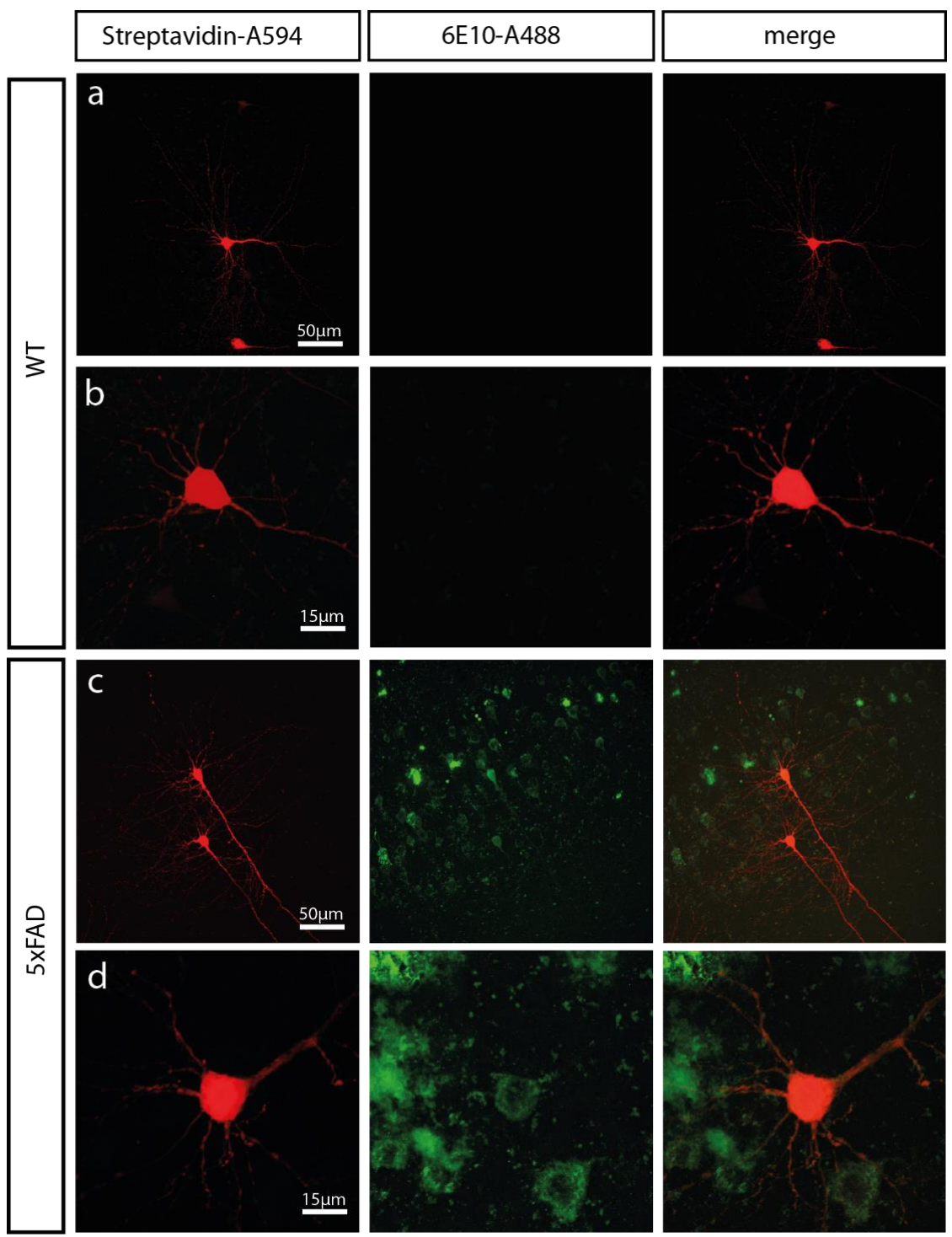

Figure 1. The somatosensory cortex of 6-months-old 5xFAD mice displays abundant amyloid beta $(\mathrm{A} \beta)$ load. Low $(\mathbf{a}+\mathbf{c})$ and high-magnification $(\mathbf{b}+\mathbf{d})$ confocal images of biocytin-filled pyramidal cells in the somatosensory cortex of a 6-months-old 5xFAD mouse and wildtype (WT) mouse. Biocytin-filled neurons were detected by fluorescently labelled streptavidin (Streptavidin-A594; left panel). A $\beta$ protein was detected with the 6E10 antibody coupled to A488 (6E10-A488; middle panel). Merges of both channels are shown in the right panel.

\subsection{NMDAR Subunit Expression Is Regulated by $A \beta$}

$A \beta$ toxicity may occur in the cortex earlier than in other brain areas because of regional differences in the expression of NMDARs. In addition, $A \beta$ may affect NMDAR expression in cortical neurons, which in turn could lead to alterations in synapse function $[12,14]$ and ultimately to cell death [48]. Since activation of extrasynaptic NMDARs was shown to trigger cell death pathways whereas activation of synaptic NMDARs reduces cell death $[43,49,50]$, but see [51-54], we recorded synaptic and extrasynaptic NMDAR- 
mediated currents in layer 5 pyramidal cells of the somatosensory cortex in 6-months-old 5xFAD mice.

The $\alpha$-amino-3-hydroxy-5-methyl-4-isoxazolepropionic acid receptor (AMPAR)/ NMDAR ratio) was not different in somatosensory cortex pyramidal cells from 5xFAD mice compared to WT mice (Figure 2a). Given that AMPAR-mediated currents were not significantly affected in pyramidal cells of the somatosensory cortex from 5xFAD mice, evidenced by unaltered miniature excitatory postsynaptic currents (mEPSCs) (see below), these data suggest that $A \beta$ does not influence the expression of synaptic NMDARs in pyramidal cells. NMDAR current decay was also similar in 5xFAD and WT neurons (Figure 2b). Considering that the subunits GluN2A-D strongly influence deactivation kinetics [35], the unaltered decay suggests that $A \beta$ does not affect NMDAR composition in pyramidal cells of the somatosensory cortex. Of note, the decay time constant ( $29 \mathrm{~ms})$ indicates that synaptic NMDARs are pure GluN1/GluN2A receptors [31,55].

a

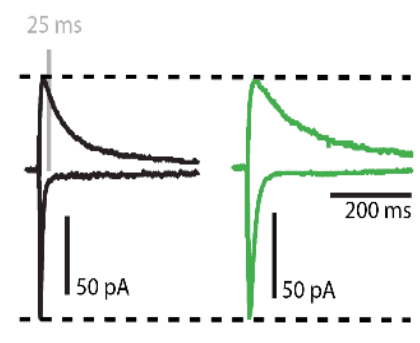

C

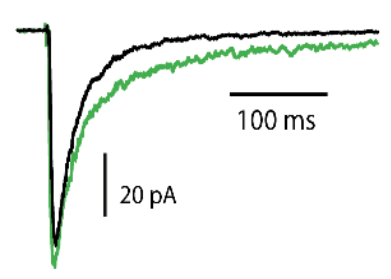

b
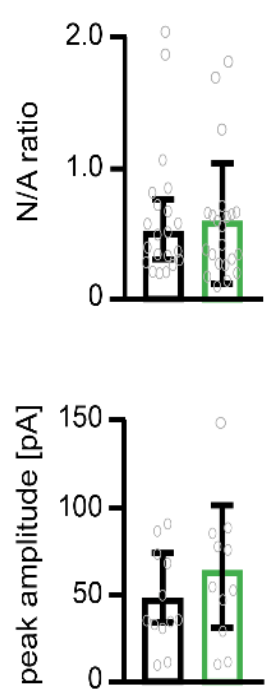

d
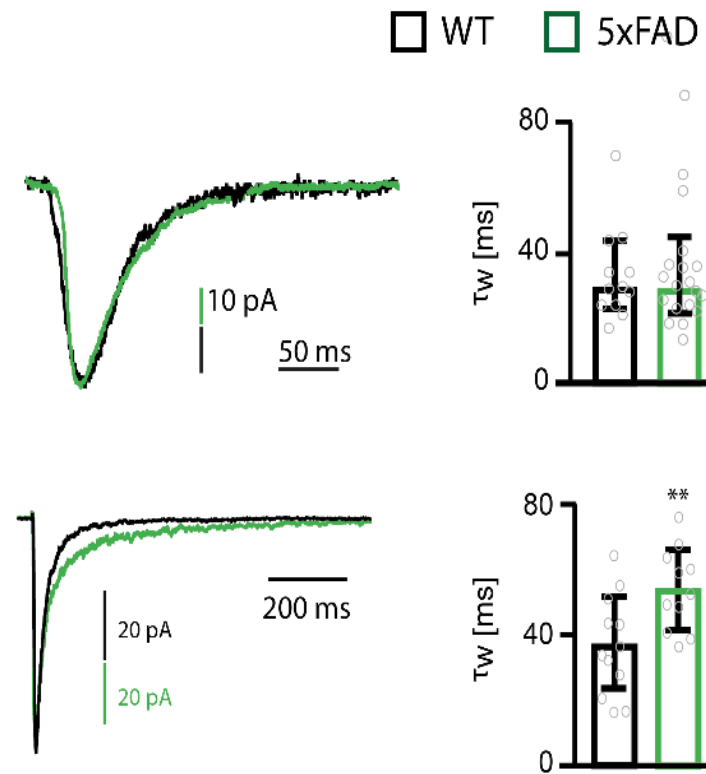
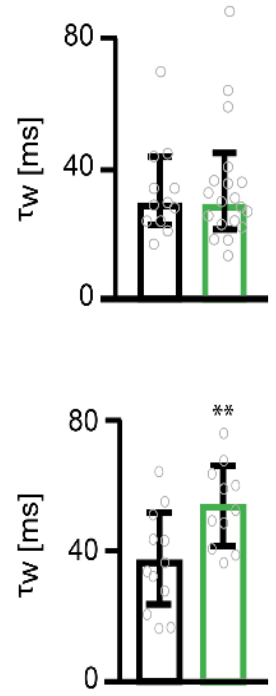

Figure 2. Deactivation time constant of extrasynaptic NMDAR currents increases in somatosensory cortex pyramidal cells of 5xFAD mice. (a) Example traces of NMDAR and AMPAR-mediated currents and bar graph of the NMDA/AMPA ratios (N/A ratios) of pyramidal cells from wildtype (WT) (black, $n=21$ ) and 5xFAD (green, $n=22)$ mice. (b) Example traces and bar graph of the decay weighted tau $\left(\tau_{\mathrm{w}}\right)$ of NMDAR-mediated currents of pyramidal cells from WT $(n=12)$ and $5 \times \mathrm{xAD}$ $(n=20)$ mice. (c) Example traces of extrasynaptic NMDAR-mediated currents recorded by ultra-fast application of glutamate onto nucleated patches obtained from somatosensory cortex pyramidal cells of WT (black) and 5xFAD (green) mice. Peak amplitudes (WT $n=12$ vs. $5 x F A D n=11$ ) of NMDAR-mediated currents are shown in the bar graph. (d) Example traces of normalized extrasynaptic NMDAR-mediated currents recorded by ultra-fast application of glutamate onto nucleated patches obtained from somatosensory cortex pyramidal cells of WT (black) and 5xFAD (green) mice. Weighted time constants $\left(\tau_{\mathrm{w}}\right)$ of NMDAR-mediated current deactivation are shown in the bar graph (WT $n=12$ vs. $5 x \mathrm{FAD} n=11$ ). Data in bar graphs are shown as median \pm interquartile range. Empty grey circles depict single data points. $t$-test: ${ }^{* *} p<0.001$.

Extrasynaptic NMDARs were investigated by ultra-fast application of glutamate onto nucleated patches of pyramidal cells of the somatosensory cortex of 6-months-old 5xFAD mice. This analysis revealed no difference in the peak amplitude of NMDARmediated currents (Figure 2c), but an increase in the deactivation time constant ( $t$-test; $p=0.0084$ ) (Figure 2d). These data suggest that the number of extrasynaptic NMDARs is unaltered in 5xFAD mice, but that there is an increase in the contribution of slow deactivating GluN2B-containing NMDARs [31]. However, the deactivation time constant of extrasynaptic NMDAR-mediated currents $(\sim 35 \mathrm{~ms})$ in pyramidal cells of WT mice suggests that also extrasynaptic NMDARs are by and large GluN1/GluN2A receptors with a small contribution of triheteromeric GluN1/GluN2A/GluN2B receptors [31,55]. 
In addition, the deactivation of extrasynaptic NMDARs in 5xFAD mice is still very fast (52 ms), suggesting that the majority of NMDARs comprise GluN1/GluN2A receptors and GluN1/GluN2A/GluN2B with very little, if at all, contribution of diheteromeric GluN1/GluN2B receptors.

\subsection{NMDAR Subunits Are Involved in Mediating Spine Loss in Somatosensory Cortex Pyramidal Cells of 5XFAD Mice}

Previous studies suggested that NMDARs and in particular those containing the GluN2B subunit mediate A $\beta$-toxicity in hippocampal neurons. We asked whether NMDARs play a similar role in cortical neurons and investigated the involvement of the GluN1, GluN2B, and GluN2A subunits in A $\beta$-mediated changes on dendritic spine number and synapse function.

Spine number was decreased by about $12 \%$ in pyramidal cells of the somatosensory cortex of 6-months-old 5xFAD mice when compared to control mice ( $t$-test; $p=0.0443$ ) (Figure $3 b, c)$. To investigate the requirement of NMDARs for this effect, we deleted GluN1, GluN2B, or GluN2A by stereotactc injection of Cre-recombinase expressing rAAVs into the somatosensory cortex of conditional NMDAR knockout mice [46]. Spine number was not different between neurons with GluN1 deletion $\left(\mathrm{GluN1}^{-/-}\right)$and neurons of 5xFAD mice with GluN1 deletion (5xFAD/GluN1 ${ }^{-/-}$) (Figure 3b), suggesting that NMDARs are required for the $A \beta$-mediated spine loss. Similarly, there was no difference in spine number of somatosensory cortex pyramidal cells with GluN2B deletion (GluN2B ${ }^{-/-}$) and cells of $5 \times$ FAD mice with GluN2B deletion (5xFAD/GluN2B ${ }^{-1-}$ ) as well as in cells with GluN2A deletion (GluN2A ${ }^{-/-}$) and cells of 5xFAD mice with GluN2A deletion $\left(5 \times F A D / G_{1 u N 2 A^{-/-}}\right)$(Figure $\left.3 b\right)$. There were $0.18 / \mu \mathrm{m}$ fewer spines in pyramidal neurons of $5 \times$ FAD mice than in pyramidal neurons of WT mice (3c). There was a trend to a smaller decrease in spine number in neurons with GluN1, GluN2B, and GluN2A deletion ( $\Delta$ spine number between GluN1 ${ }^{-/-}$and $5 \times \mathrm{xAD} / \mathrm{GluN1}^{-/-}: 0.04 / \mu \mathrm{m} ; \Delta$ spine number between GluN2B $^{-/-}$and $5 \times F A D / G_{l u N 2 B}{ }^{-/-}: 0.02 / \mu \mathrm{m} ; \Delta$ spine number between GluN2A ${ }^{-/-}$

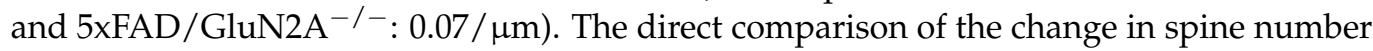
indicates that GluN2B- and GluN2A-containing NMDARs may play a role in A $\beta$-toxicity in cortical neurons. Of note, deletion of GluN1, GluN2B, and GluN2A per se reduced spine number in somatosensory cortex pyramidal cells (i.e., compared to spine number in WT mice), suggesting that NMDARs control the number of spines in cortical neurons.
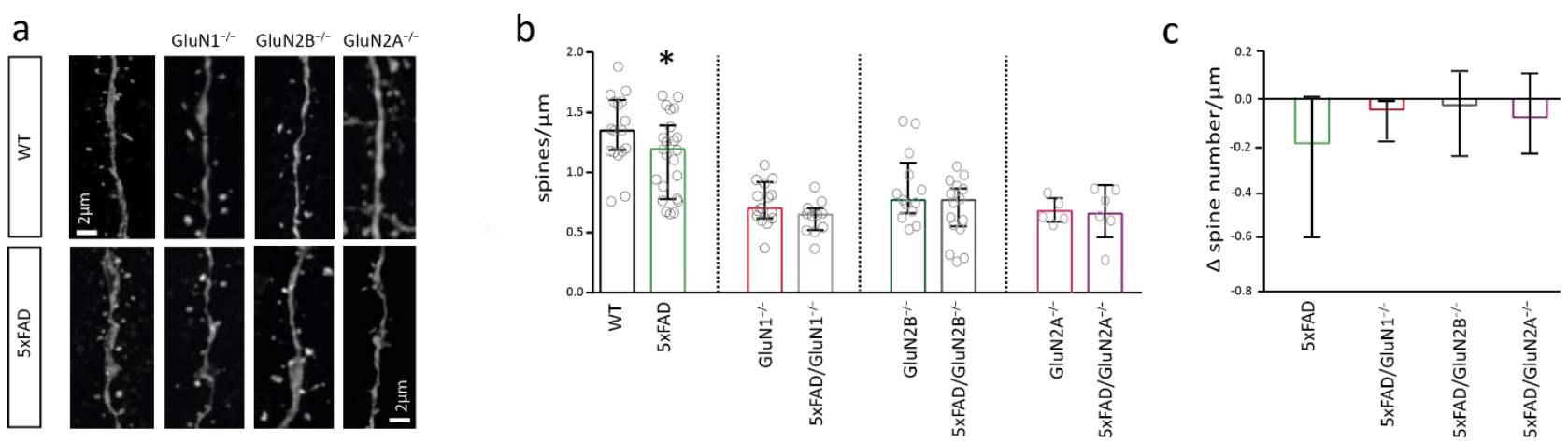

Figure 3. Loss of dendritic spines in 5xFAD mice depends on NMDARs. (a) Sample images of dendrites containing spines of pyramidal cells of the somatosensory cortex of wildtype (WT) and 5xFAD mice with and without deletion of GluN1, GluN2B, and GluN2A. (b) Bar graph showing the number of spines per $\mu \mathrm{m}$ in neurons of WT $(n=17)$ and $5 x F A D(n=23)$ mice (left), in neurons with GluN1 deletion (middle left) $\left(n=15 \mathrm{GluN1}{ }^{-/}-\right.$vs. $\left.n=105 x \mathrm{xAD} / \mathrm{GluN1}{ }^{-/}\right)$, GluN2B deletion

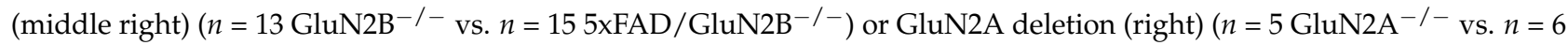
$5 \mathrm{xFAD} / \mathrm{GluN} \mathrm{A}^{-/-}$). (c) Bar graph showing the $\Delta$ spine number $/ \mu \mathrm{m}$ in pyramidal cells from $5 \mathrm{xFAD}$ mice when compared to the respective control mouse (WT, GluN1 ${ }^{-/-}, \mathrm{GluN}_{2} \mathrm{~B}^{-/-}$, GluN2A ${ }^{-/-}$), quantified from data in (b). Data in bar graphs are shown as median \pm interquartile range. Empty grey circles depict a single data point. $t$-test: ${ }^{*} p<0.05$. 


\subsection{NMDARs Are Involved in Mediating the Decrease in Functional Synapse Number in Pyramidal Cells of the Somatosensory Cortex of 5xFAD Mice}

Glutamatergic synapses are located on dendritic spines. We therefore investigated whether the spine loss was accompanied by changes in functional synapse number.

Synaptic function was analyzed by recording mEPSCs from somatosensory cortex pyramidal cells of 6-months-old control and 5xFAD mice. mEPSC frequency is commonly used as an estimation of the number of functional synapses of a neuron, whereas mEPSC peak amplitude gives an estimation of the number of AMPARs per synapse [56].

mEPSC frequency was not altered in 5xFAD mice compared to WT controls (Figure 4d). There was no difference in mEPSC frequency between neurons from WT and 5xFAD mice with GluN1 (red bar vs. grey bar) or GluN2A deletion (pink bar vs. lilac bar) (Figure 4d). A subtle increase of mEPSC frequency was found in neurons of 5xFAD mice with GluN2B deletion (green bar vs. dark grey bar; Mann-Whitney test: ${ }^{*} p=0.0398$; Figure $4 \mathrm{~d}$ ). This increase in mEPSC frequency was not significantly different to the change in mEPSC frequency in neurons without NMDAR deletion (Kruskal-Wallis: ${ }^{* *} p=0.0029$; Figure 4e). Overall, in 6-months-old 5xFAD mice, somatosensory cortex pyramidal cells do not show deficits in functional synapse number. To see whether functional synapse number was affected in older 5xFAD, when the disease progressed further, we recorded mEPSCs in 1-year-old pyramidal cells of the somatosensory cortex. At this age, we had previously shown a loss of functional synapse number in dentate gyrus granule cells (Mueller et al., 2018). However, mEPSC frequency and peak amplitude were not affected in 1-year-old somatosensory cortex pyramidal cells from 5xFAD mice (Supplementary Materials Figure S1). mEPSC amplitude was slightly increased in neurons of 6-months-old 5xFAD mice (Mann-Whitney test: * $p=0.0428$; Figure $4 \mathrm{f}$ ), but not significantly affected in somatosensory cortex pyramidal cells of 5xFAD mice with deletion of GluN1, GluN2B or GluN2A (Figure 4f). However, the changes in mEPSC amplitudes in neurons without and with NMDAR subunit deletion were not significantly different from each other (Figure $4 \mathrm{~g}$ ).

a

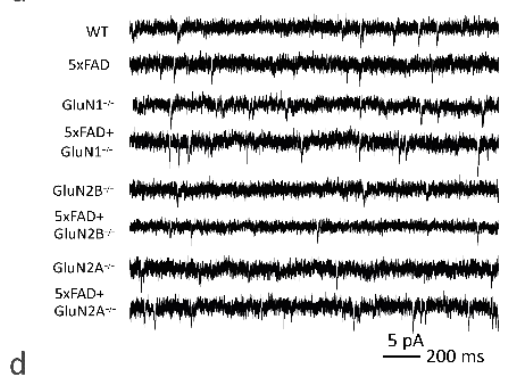

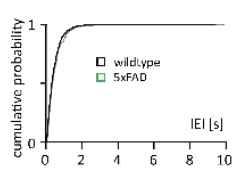

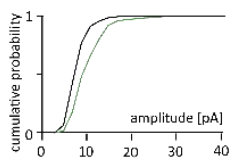

e

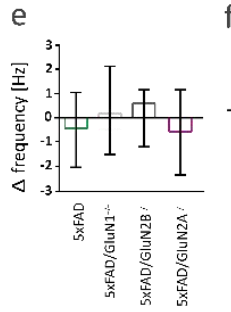

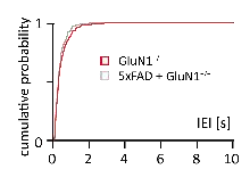

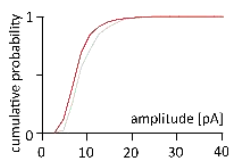

f
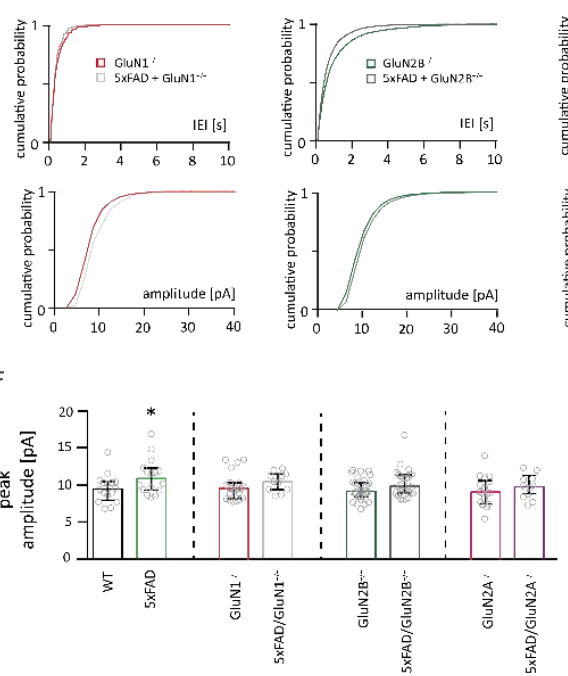
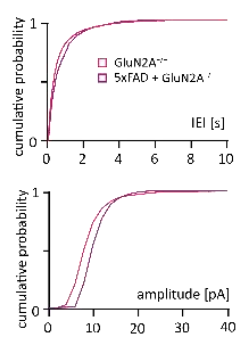

g

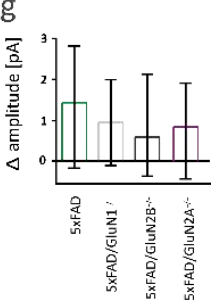

Figure 4. Functional synapses are only mildly affected in pyramidal cells of the somatosensory cortex from 5xFAD mice. (a) Sample traces of miniature excitatory postsynaptic current (mEPSC) recordings. (b) Cumulative distribution plots of the median inter-event-intervals (IEI) of mEPSCs of pyramidal cells of the somatosensory cortex. (c) Cumulative distribution plots of the median amplitudes of mEPSCs. (d) Bar graphs of mEPSC frequencies neurons of wildtype $(\mathrm{WT})(n=16)$ and $5 x$ FAD $(n=16)$ mice (left), with deletion of GluN1 (middle left) $\left(n=22 \mathrm{GluN}^{-/-}\right.$vs. $\left.n=115 \times \mathrm{xAD} / \mathrm{GluN1} 1^{-/-}\right)$or GluN2B

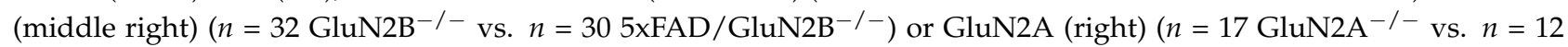
$5 \times \mathrm{xAD} / \mathrm{GluN} \mathrm{A}^{-/-}$). (e) Bar graph showing the change in mEPSC frequency in pyramidal cells from $5 \times \mathrm{xAD}$ mice when 
compared to the respective control mouse (WT, GluN1 ${ }^{-/-}$, GluN2B ${ }^{-/-}, \mathrm{GluN}_{2} \mathrm{~A}^{-/-}$), quantified from data in (d). (f) Bar graphs of peak amplitudes of mEPSCs from WT and 5xFAD mice (left) with GluN1 (middle left) or GluN2B (middle right) or GluN2A (right) deletion. (g) Bar graph showing the change in mEPSC amplitude in pyramidal cells from 5xFAD mice when compared to the respective control mouse (WT, GluN1 ${ }^{-/-}, \mathrm{GluN}^{-} \mathrm{B}^{-/-}, \mathrm{GluN}_{2} \mathrm{~A}^{-/-}$), quantified from data in (f). Data in bar graphs are shown as median \pm interquartile range. Empty grey circles depict single data points. Mann-Whitney test/Kruskal-Wallis test: ${ }^{*} p<0.05$.

\subsection{Neuronal Excitability of Somatosensory Cortex Pyramidal Cells Is Not Altered in 5xFAD Mice}

$A \beta$-mediated changes of intrinsic properties of neurons [57-59] were discussed to contribute to neuronal hyperactivity in AD patients and mouse models [60]. We therefore investigated whether action potential properties and firing was altered in pyramidal cells in the somatosensory cortex of 6-months-old 5xFAD mice.

Intrinsic properties including action potential threshold, amplitude, duration, input resistance, afterhyperpolarization (Figure $5 \mathrm{~b}$ ), as well as firing behavior measured by action potential firing frequency; early and late adaptation of firing were not different between pyramidal cells from WT and 5xFAD mice (Figure 5d). Thus, 6-month overexpression of $\mathrm{A} \beta$ in $5 \times \mathrm{xAD}$ mice did not influence active and passive electrophysiological properties of pyramidal cells in the somatosensory cortex and suggests that $A \beta$-toxicity is comparably mild at this age despite the presence of intracellular $A \beta$ accumulation and extracellular $\mathrm{A} \beta$ plaques.

a

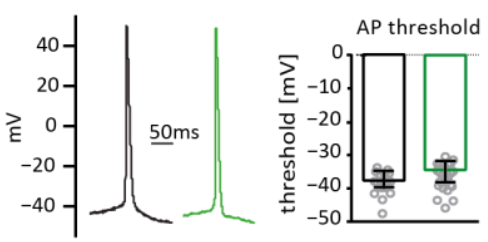

C

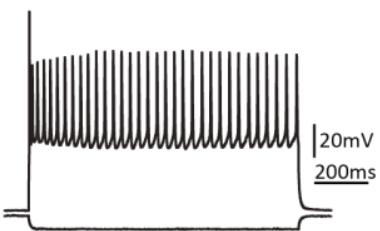

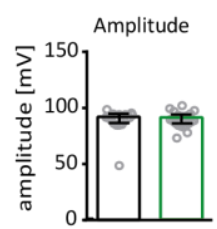

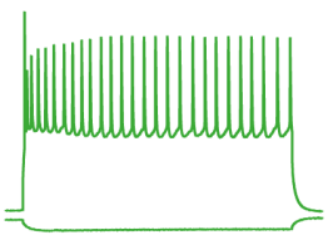

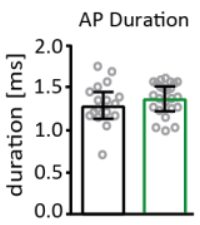
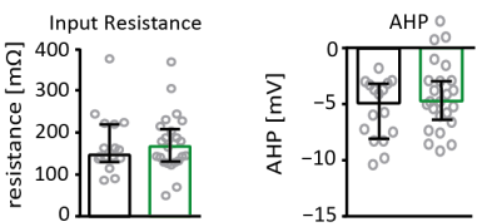

$\square$ WT $\square$ 5xFAD
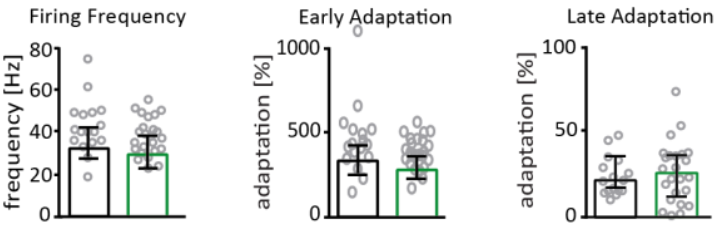

Figure 5. 5xFAD somatosensory cortex pyramidal cells display unaltered intrinsic electrophysiological properties and firing behavior. (a) Example traces of action potentials recorded from pyramidal cells of the somatosensory cortex of wildtype (WT) (black) and 5xFAD (blue) mice. (b) Bar graphs displaying action potential (AP) threshold, AP amplitude and duration, input resistance, and afterhyperpolarization (AHP) of pyramidal cells from WT (black; $n=17$ ) and 5xFAD mice (green; $n=24$ ). (c) Example traces of action potential firing patterns recorded from somatosensory cortex pyramidal cells of WT (black) and 5xFAD (green) mice. (d) Bar graphs of firing frequency, early and late adaption of pyramidal cells from WT (black), and 5xFAD (green) mice. Data in bar graphs are shown as median \pm interquartile range. Empty grey circles depict single data points.

\subsection{Spine Number Is Increased after Short-Term Overexpression of $A \beta$ in the Somatosensory Cortex}

The deletion of NMDARs per se reduced spine number in somatosensory cortex pyramidal cells in 6-months-old WT mice (Figure 3b), which may obscure effects of A $\beta$ on spine number. It was previously shown that deletion of GluN2B reduces spine number also in CA1 neurons [61]. However, the reduction in CA1 neurons is more subtle, which may be explained by the much shorter period of NMDAR deletion (2-3 weeks) in that study compared to the 3-month deletion in our study. We therefore investigated the involvement of NMDARs on $A \beta$-toxicity in an additional model in which we overexpressed $A \beta$ and deleted NMDARs in somatosensory cortex pyramidal cells for a much shorter time period. 
To this end, we induced the overexpression of $\mathrm{A} \beta$ by injecting into the somatosensory cortex of adult WT mice an rAAV (rAAV-CaMKII-CT100(I716F)-T2A-tdTom), which expresses the penultimate $A \beta$ precursor $C T 100(\mathrm{I716F})$, harboring a mutation that increases the $A \beta 42 / A \beta 40$ ratio [62] and tdTomato to detect infected neurons. NMDAR subunit deletion was induced by co-injection of an rAAV coding for Cre-recombinase into conditional NMDAR knockout mice. Functional and anatomical analyses were performed 3 weeks after virus-injection [46].

Anatomical analysis of pyramidal cells of the somatosensory cortex revealed that 3 weeks $A \beta$-overexpression increased spine number when compared to control cells (MannWhitney test: ${ }^{* * *} p=0.0002$ ) (Figure 6b). Deletion of GluN1 or GluN2B for 3 weeks did not affect spine number of somatosensory cortex pyramidal cells. This is in contrast to the reduction of spine number after 3-month deletion of GluN1 or GluN2B (Figure 3b). $A \beta$-overexpression did not significantly increase spine number in neurons with GluN1 or GluN2B deletion. The direct comparison of the $A \beta$-induced change in spine number revealed that deletion of the GluN1 subunit significantly prevented the $A \beta$-mediated increase in spine number (Figure $6 \mathrm{c}$ ). In contrast, there was a trend for an $A \beta$-mediated increase in spine number in neurons with GluN2B deletion, which was not significantly different to the $A \beta$-mediated increase in control neurons (Figure $6 c$ ). Thus, the $A \beta$-mediated formation of new synapses was regulated by NMDARs.

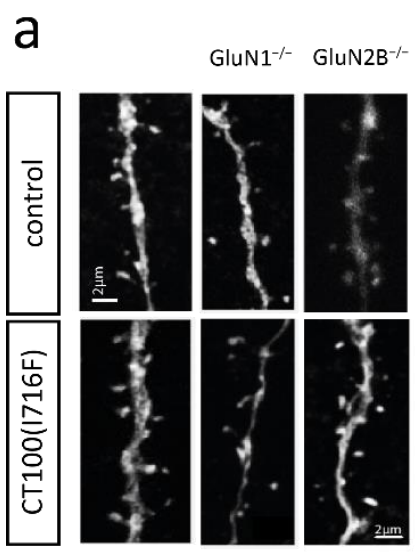

b

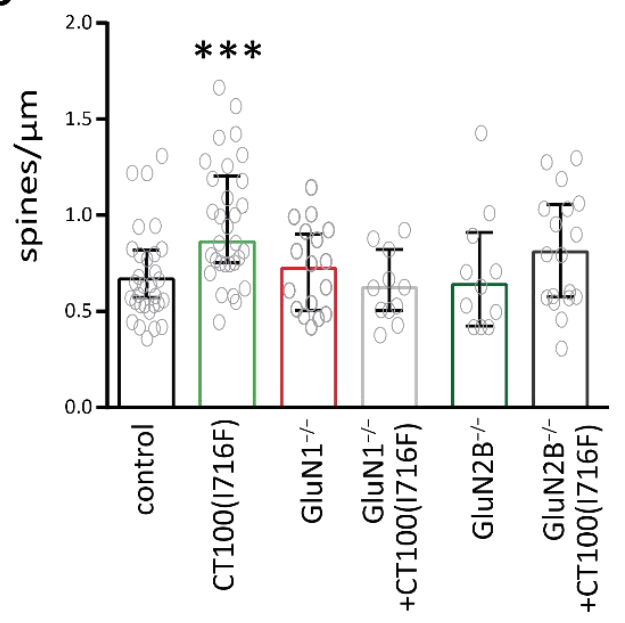

C

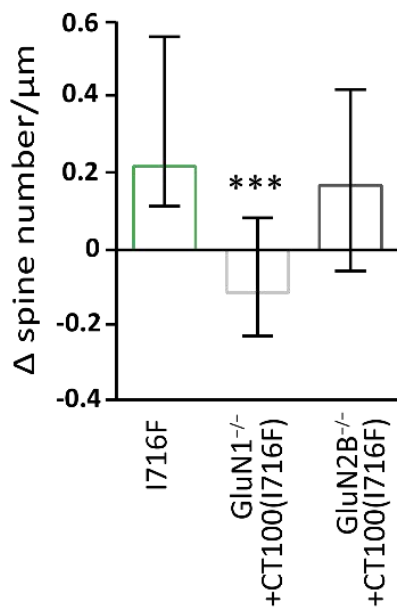

Figure 6. Increase in dendritic spine number in pyramidal cells of the somatosensory cortex of amyloid beta (A $\beta$ )overexpressing mice is mediated by the GluN1 subunit. (a) Sample images of dendritic spines of pyramidal cells of the somatosensory cortex without (control) and with CT100(I716F)-overexpression without (left) and with deletion of GluN1 (middle) and GluN2B (right). (b) Bar graph showing the number of spines per $\mu \mathrm{m}$ of control $(n=31)$ and CT100(I716F)overexpressing $(n=31)$ neurons (left) with GluN1 deletion (middle) ( $n=17 \mathrm{GluN1}^{-/{ }^{-}}$vs. $n=11 \mathrm{CT100}(\mathrm{I716F}) / \mathrm{GluN1}{ }^{-/-}$) or GluN2B deletion (right) ( $n=11 \mathrm{GluN}^{-\mathrm{B}^{-/}}$vs. $n=8 \mathrm{CT} 100(\mathrm{I716F}) / \mathrm{GluN}^{-\mathrm{B}^{-/}}$). (c) Bar graph showing the change in spine number in pyramidal cells from CT100(I716F)-overexpressing neurons when compared to the respective control neurons (control, GluN1 ${ }^{-/-}$, GluN2B ${ }^{-/-}$) quantified from data in (b). Data in bar graphs are shown as median \pm interquartile range. Empty grey circles depict single data points. $t$-test; Kruskal-Wallis-test: ${ }^{* *} p<0.001$.

We previously showed that functional synapse number was reduced, while spine number was unaffected in dentate gyrus granule cells overexpressing $A \beta$, suggesting an increase in immature synapses that do not contain AMPARs [46].

\subsection{NMDAR Subunits Are Involved in A $\beta$-Mediated Changes in Functional Synapse Number}

AMPAR-mediated mEPSCs were recorded in order to study synapse functionality after 3 weeks of virus-mediated A $\beta$-overexpression. mEPSC frequency was reduced by about $42 \%(0.89 \mathrm{~Hz})$ in A $\beta$-overexpressing pyramidal cells (Mann-Whitney test: ${ }^{* * *} p=0.0003$ ) (Figure $7 \mathrm{~d}$ ), consistent with a reduction in functional synapse number. Importantly, A $\beta$ - 
overexpression did not reduce mEPSC frequency in neurons with deletion of GluN1 or GluN2B. Direct comparison of the change in mEPSC frequency revealed that the A $\beta$ mediated change in mEPSC frequency was significantly different in neurons without NMDAR deletion from neurons with GluN2B deletion (Figure 7e). mEPSC peak amplitudes were not different between genotypes (Figure $7 \mathrm{f}, \mathrm{g}$ ).

a

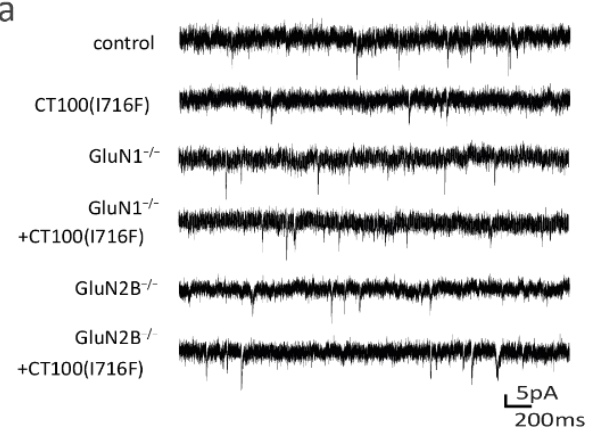

b
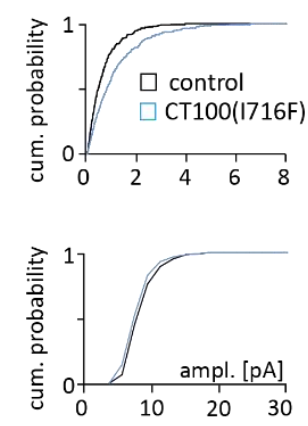
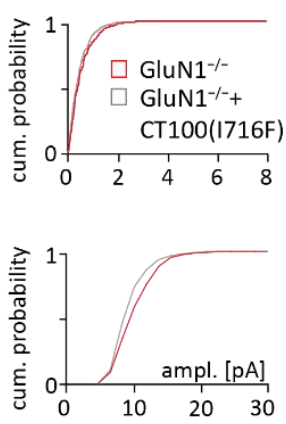
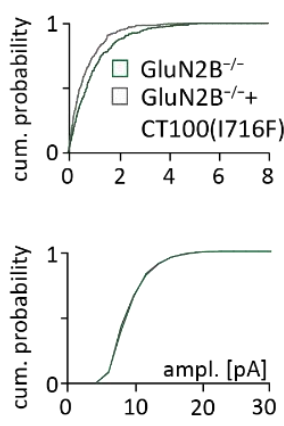

g d

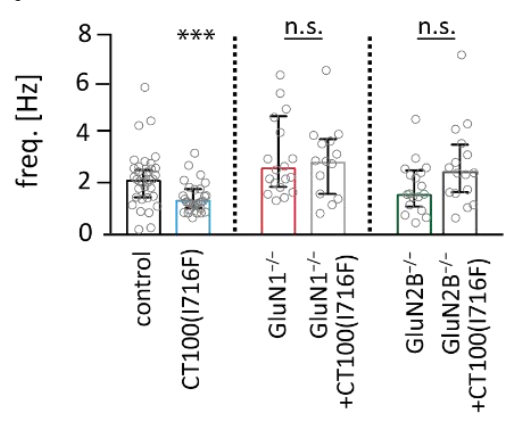

e

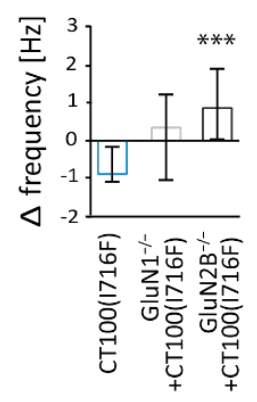

$\mathrm{f}$

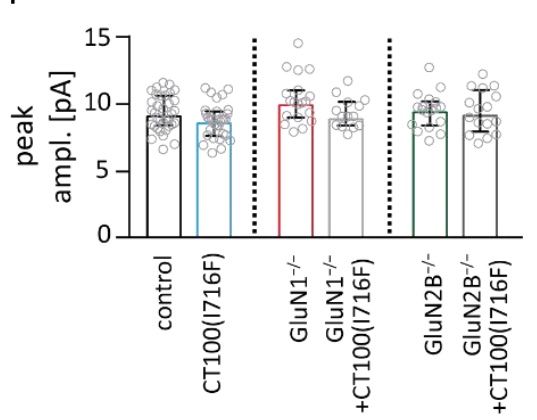

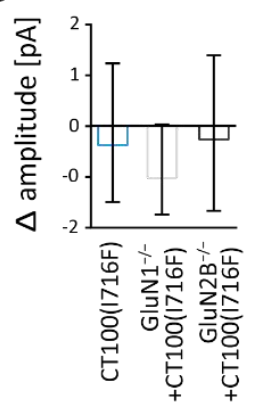

Figure 7. Reduction in miniature excitatory postsynaptic current (mEPSC) frequency is NMDAR-dependent in somatosensory cortex pyramidal cells of amyloid beta (A $\beta$ )-overexpressing neurons. (a) Sample traces of mEPSC recordings. (b) Cumulative distribution plots of the median inter-event-intervals (IEI) of mEPSCs from pyramidal cells of the somatosensory cortex. (c) Cumulative distribution plots of the median amplitudes (IEI) of mEPSCs. (d) Bar graphs of mEPSC frequencies of control $(n=35)$ and CT100(I716F)-overexpressing $(n=31)$ neurons without (left) and with deletion of GluN1 (middle) ( $n=19$

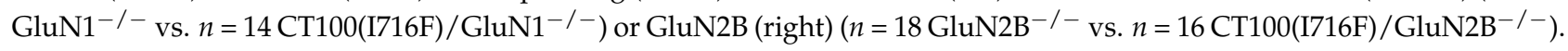
(e) Bar graph showing the change in mEPSC frequency in pyramidal cells from CT100(I716F)-overexpressing neurons when compared to the respective control neurons (control, GluN1 ${ }^{-/-}, \mathrm{GluN}_{2} \mathrm{~B}^{-/}$), quantified from data in (d). (f) Bar graphs of peak amplitude of mEPSCs from control and CT100(I716F)-overexpressing neurons without (left) and with deletion of GluN1 (middle) or GluN2B (right). (g) Bar graph showing the change in mEPSC amplitude in pyramidal cells from CT100(I716F)-overexpressing neurons when compared to the respective control neurons (control, GluN1 ${ }^{-/-}, \mathrm{GluN}^{-\mathrm{B}^{-/-}}$), quantified from data in (f). Data in bar graphs are shown as median \pm interquartile range. Empty grey circles depict single data points. Mann-Whitney test/Kruskal-Wallis test: ${ }^{* * *} p<0.001$.

The decrease in mEPSC frequency shows that A $\beta$-overexpression reduces functional synapse number in pyramidal cells of the somatosensory cortex, which is prevented by deletion of the GluN1 or GluN2B. This indicates that GluN2B-containing NMDARs are involved in the $\mathrm{A} \beta$-mediated reduction in functional synapse number.

\section{Discussion}

The progression of $\mathrm{AD}$ pathology follows distinct patterns in the brains of $\mathrm{AD}$ patients and also in AD mouse models [2,3]. The neocortex is a brain region that is involved very early in AD in human patients [2] and in AD model mice. Thus, cortical plasticity in the somatosensory cortex is more impaired compared to the hippocampus in 6-months-old 5xFAD mice [63]. Consistently, spine loss-a common pathology in AD mouse models and human AD patients-is present in pyramidal cells of the somatosensory cortex but not in dentate gyrus granule cells of 6-months-old 5xFAD mice (this study and $[7,46])$. Dentate 
gyrus granule cells are not resistant to A $\beta$-toxicity, but spine loss commences later and is significantly smaller in dentate gyrus granule cells of 1-year-old 5xFAD mice [46].

Memantine, an NMDAR open-channel blocker, is widely used to treat moderatesevere $\mathrm{AD}$ in human patients [8,9]. In addition, there is ample evidence from mouse studies that NMDARs and, in particular, the slow-deactivating GluN2B-containing NMDARs are involved in $A \beta$-toxicity $[12,15,17,21,64]$. The region-specific differences in susceptibility for A $\beta$-toxicity may therefore result from differential NMDAR expression. Knowledge of the brain-region specific composition and contribution of the NMDAR subunits to AD pathophysiology could be important for the development of novel AD treatments. For example, antagonists that are specific for AD-relevant NMDAR compositions might be more efficient than memantine without the cost of stronger side effects. Antagonists that are more specific for triheteromeric NMDARs could be more beneficial than memantine for the treatment of AD patients considering the upregulation of triheteromeric NMDARs at extrasynaptic sites in 5xFAD somatosensory pyramidal cells. The composition of NMDARs can be estimated from deactivation kinetics. Thus, deactivation is fast for NMDARs containing the GluN2A subunit, slower for NMDARs containing the GluN2B or GluN2C subunit, and very slow for NMDARs containing the GluN2D subunit [32]. Synaptic NMDAR-mediated currents of somatosensory cortex pyramidal cells decay very fast. The decay time constant of $\sim 35 \mathrm{~ms}$ is similar to the deactivation time constant of diheteromeric GluN1/GluN2A NMDARs (23 ms; [65]), which indicates that the contribution of NMDARs containing the GluN2B, GluN2C or GluN2D subunit is negligible in synapses of somatosensory cortex pyramidal cells.

Importantly, the subcellular localization of NMDARs is relevant for the role in toxicity [49]. Thus, synaptic NMDARs mediate pro-survival signaling via CREB activation, whereas the activation of extrasynaptic NMDARs induces cell-death pathways [43]. Excessive activation of extrasynaptic NMDAR signaling, partially due to an increase in extrasynaptic NMDAR number, was shown in different neurodegenerative diseases, including AD $[42,66]$. The detrimental role of extrasynaptic NMDARs in neurodegenerative diseases has been connected with a preferential extrasynaptic expression of GluN2B-containing NMDARs, which display slow deactivation kinetics [35]. We therefore tested whether the expression of extrasynaptic NMDARs with particular slow deactivation kinetics could explain the sensitivity of somatosensory cortex pyramidal cells to A $\beta$-toxicity. However, the deactivation of extrasynaptic NMDARs was also very fast (35 ms) and consistent with the expression of mostly diheteromeric GluN1/GluN2A NMDARs. In fact, decay of synaptic NMDAR-mediated currents and deactivation of extrasynaptic NMDAR-mediated currents was much faster than in dentate gyrus granule cells [46]. The decay time constant ( $63 \mathrm{~ms}$ ) of synaptic NMDAR-mediated currents and deactivation time constant ( $75 \mathrm{~ms}$ ) of extrasynaptic NMDAR-mediated currents in dentate gyrus granule cells is consistent with the expression of triheteromeric GluN1/GluN2A/GluN2B NMDARs or a mixture of diheteromeric GluN1/GluN2A and GluN1/GluN2B NMDARs [46]. Moreover, the amplitude of extrasynaptic NMDAR-mediated currents was considerably lower in pyramidal cells of the somatosensory cortex ( $36 \mathrm{pA})$ than in dentate gyrus granule cells ( 125 pA; [46]), indicating that the number of extrasynaptic NMDARs is much smaller in pyramidal cells than in dentate gyrus granule cells. Thus, differences in the expression of NMDARs unlikely explain the higher susceptibility of cortical neurons than hippocampal neurons to $A \beta$-toxicity.

However, the slower deactivation of extrasynaptic NMDAR-mediated currents in pyramidal cells of 5xFAD mice than in WT mice suggests that A $\beta$ changes the composition of NMDARs by increasing the number of receptors containing the GluN2B subunit. Of note, the deactivation time constant $(52 \mathrm{~ms})$ is close to that of triheteromeric GluN1/GluN2A/GluN2B NMDARs (78 ms; [31]). This indicates that extrasynaptic NMDARs in pyramidal cells of the somatosensory cortex in 5xFAD mice are a mixture of triheteromeric GluN1/GluN2A/GluN2B and diheteromeric GLuN1/GluN2A NMDARs. Considering that the activation of extrasynaptic GluN2B-containing NMDARs induces 
cell death [43], the replacement of fast GluN1/GluN2A NMDARs by slower deactivating GluN2B-containing triheteromeric NMDARs may contribute to A $\beta$-toxicity in pyramidal cells of the somatosensory cortex. The GluN1 gene can be alternatively spliced into eight different isoforms [67]. These splice variants are differently expressed in different brain areas and determine NMDAR function, gating, and kinetics [68-75]. Thus, another possible explanation for the increase in the deactivation time constant could be the incorporation of NMDARs containing GluN1 subunits that lack the alternatively spliced exon 5 [70]. To our knowledge, there is no data available on disease-induced alterations on the expression of GluN1 subunit.

In contrast to the findings in pyramidal cells of the somatosensory cortex, there is no increase in the decay or deactivation time constants in dentate gyrus granule cells of 5xFAD mice [46]. However, A $\beta$ decreased the amplitude of synaptic and extrasynaptic NMDARmediated currents by nearly $50 \%$ in dentate gyrus granule cells [46]. A downregulation of NMDARs may possibly protect dentate gyrus granule cells from NMDAR-dependent $A \beta$ pathologies. Thus, the data suggest that regional differences in susceptibility to $A \beta-$ toxicity do not result from differential expression of NMDAR subunits but more likely from region-specific regulations in NMDAR expression.

Spine number was reduced, as expected [7], in pyramidal cells of the somatosensory cortex of 6-months-old 5xFAD mice. Interestingly, 3 weeks $A \beta$ overexpression increased spine number in pyramidal cells of the somatosensory cortex. Although not significant, there was a trend to increase spine numbers also in dentate gyrus granule cells after 3 weeks of $A \beta$ overexpression. An increased spine number was also observed by others after overexpression of full-length APP [76]. The most likely explanation for opposite effects on spine number is the difference in the duration of $A \beta$ overexpression. Chronic $A \beta$ overexpression is known to be toxic $[77,78]$. In contrast, the model with short-time $A \beta$ overexpression may reveal the physiological role of A $\beta$ or the APP intracellular domain (AICD) on synaptic activity and morphology [79-83]. AICD-proteolytic products were shown to translocate to the nucleus where they can activate transcription factors and thus alter the synaptic function [83-86]. Indeed, APP itself, as well as its homologues and cleavage products, affect dendritic spine numbers [76,87-90].

We deleted GluN1 and GluN2B by virus-mediated expression of Cre-recombinase in conditional NMDAR subunit knockout mice to investigate the role of NMDARs on the $A \beta$-induced changes in spine number and synapse function. Interestingly, NMDARs are required for the increase in spine number after 3-week $A \beta$ overexpression as well as the decrease in spine number in 5xFAD mice. Deletion of the GluN2B subunit was not sufficient to prevent the increase in spine number after 3-week $A \beta$ overexpression, perhaps indicating that GluN2A-containing NMDARs mediate this effect.

The interpretation of the requirement of NMDARs for the effect of $A \beta$ on spine number is somewhat compromised by the fact that deletion of NMDARs alone strongly reduces spine number after NMDAR subunit deletion for 12 weeks in 6-month old mice, but not after 3 weeks in 3-month old mice. Thus, the duration of NMDAR absence and/or the age of the animal seem to be critical. Spines can be classified as transient (lifetime of minutes to hours) and persistent (lifetime of days to months) [91,92]. The largest fraction of spines are of the persistent type in the somatosensory cortex of adult mice [91,93]. The slow turnover explains therefore that spine loss is present 12 weeks but not 3 weeks after NMDAR deletion. It is known that NMDARs influence synapse development and stability [22]. However, the role of NDMARs for spine number appears to be region specific. Thus, deletion of NMDARs does not reduce spine number in dentate gyrus granule cells [46]. Spine number is reduced by deletion of GluN2B but not of GluN1 or GluN2A in CA1 neurons [61]. The effect appears to be smaller than in pyramidal cells of the somatosensory cortex, which may be explained by the different cell type or by the shorter period of GluN2B absence ( 3 weeks) in Ca1 pyramidal cells in the study of Gray and colleagues compared to the 12 weeks absence in pyramidal cells in our study. Finally, deletion of GluN2B reduces spine number also in CA3 pyramidal cells [94]. The decreased spine number in neurons with 
GluN2B deletion may be surprising as the findings from electrophysiological recordings suggested that pyramidal cells of the somatosensory cortex express if at all only very few GluN2B-containing NMDARs. However, one has to keep in mind that the GluN2B subunit is downregulated with development [35]. We deleted GluN2B in 3-months-old mice, 12 weeks prior to functional and morphological analysis. Thus, it is possible that the effect of GluN2B deletion on spine number results from the long-time absence of GluN2B, which includes also an age-period at which pyramidal cells of the somatosensory cortex express GluN2B.

How could the requirement of NMDARs for the effect of $A \beta$ on spine number be explained? Considering the influence of NMDARs on spine number and stability [22,95], one possibility would be that $\mathrm{A} \beta$ downregulates NMDAR number in pyramidal cells of 5xFAD mice resulting in reduced NMDAR activation. However, results of electrophysiological analyses with unaltered amplitude and slowing of NMDAR-mediated currents speak against this hypothesis. Reduced glutamate re-uptake with increased ambient glutamate levels and therefore overactivation of NMDARs was discussed as a mechanism of how $A \beta$ induces toxicity [40]. Increased ambient glutamate may augment the activation of extrasynaptically NMDARs in particular [42]. Although the question of whether synaptic and extrasynaptic NMDARs play differential roles in survival and cell-death signaling is debated [96], there is ample evidence that their activation induced different intracellular signaling cascades [44,97-102]. Thus, it is also possible that synaptic and extrasynaptic NMDARs play different roles in controlling spine number. If that is the case, an increased activation of extrasynaptic NMDARs via glutamate spillover in 5xFAD mice could lead to decreased spine numbers, which would not necessarily be contradictory to the finding of decreased spine number in neurons with genetic deletion of synaptic and extrasynaptic NMDARs. The requirement of NMDARs for A $\beta$-toxicity was shown in several studies. However, it is of course also possible that the influences of $A \beta$ and NMDARs on spine number are independent of each other, but that $\mathrm{A} \beta$-overexpression and NMDAR deletion induce or inhibit the same intracellular signaling cascades. In this case, an influence of $A \beta$ on spine number might be masked in neurons with a spine number reduction due to NMDAR deletion.

Short-term $A \beta$ overexpression decreased functional synapse number in pyramidal cells of the somatosensory cortex as evidenced by the decreased mEPSC frequency. Functional synapse number was also reduced by $\mathrm{A} \beta$ in dentate gyrus granule cells [46]. This influence depended in both cell types on the presence of NMDARs. A reduction in functional synapse number may seem at odds with the increase in spine number in cells with short-term $A \beta$ overexpression. However, it can be explained by the increased formation of immature spines that do not contain AMPARs. These immature synapses, which can be converted into functional synapses by the insertion of AMPARs [103], could be built in order to compensate for the loss of functional synapses.

In conclusion, our study shows alterations in NMDAR expression and function in the somatosensory cortex of $A \beta$ over-expressing mice. NMDARs were involved in functional and structural changes observed after 3 weeks of virus-mediated $A \beta$ over-expression and in the 5xFAD mouse model. These data show a different impact of NMDAR expression and function in the somatosensory cortex compared to the role in the hippocampus shown in a previous study performed in the dentate gyrus [46]. Therefore, we argue that future investigation of the role of $A \beta$ and also Tau in AD should be done with respect to regionspecific differences in putative pathophysiological mechanisms. This may be relevant for the development of drugs targeting specific NMDAR combinations that are predominant in brain regions particularly vulnerable to $A \beta$-toxicity. Thus, early treatment with specific antagonists that act on triheteromeric (GluN1/2A/2B) NMDARs in the neocortex might be more efficient and might have fewer side-effects than broad blockade of all NMDARs by memantine. 


\section{Materials and Methods}

\subsection{Animals}

All mouse experiments and breedings were carried out in compliance with the German Animal Welfare Act and the state investigation office of Rhineland Palatinate and BadenWuerttemberg. All procedures followed the "Principles of laboratory animal care" (NIH publication No. 86-23, revised 1985).

Mice were housed in groups of up to four animals, and food and water were offered ad libitum. Mice, in which the grin 1 and grin $2 b$ genes are flanked by loxP site $\left(\mathrm{GluN}^{\mathrm{fl} / \mathrm{fl}}[104]\right.$ and GluN2B $\mathrm{B}^{\mathrm{fl} / \mathrm{fl}}[105]$ and $5 x F A D x G l u N 1^{\mathrm{fl} / \mathrm{fl}} / \mathrm{GluN}^{\mathrm{f}} \mathrm{B}^{\mathrm{fl} / \mathrm{fl}}$ lines) were used to study the effect of NMDAR subunit deletion in Alzheimer's disease (as described in [46]). Only female 5xFAD mice were used for experiments, since male and female 5xFAD show significant differences in $A \beta$ plaque load [106]. For experiments in which $A \beta$ overproduction was mediated via rAAVs, data obtained from female and male mice were pooled.

Littermates were used as controls in all experiments. In experiments with virusmediated $A \beta$ overexpression, we used GluN1 $1^{\mathrm{fl} / \mathrm{fl}}$ and GluN2 $\mathrm{B}^{\mathrm{fl} / \mathrm{fl}}$ mice injected with a tomato-expressing rAAV as control (for detail see below). We verified before that the injection of the tomato and Cre-expressing rAAVs as well as the insertion of the loxP sites per se do not alter the expression of AMPA and NMDARs (own unpublished data).

For experiments with the 5xFAD line, we injected the tomato-expressing rAAV in $5 \times F A D x G l u N 11^{\mathrm{fl} / \mathrm{fl}}$ and $5 \times \mathrm{FAD} / \mathrm{GluN} 2 \mathrm{~B}^{\mathrm{fl} / \mathrm{fl}}$ mice (termed $5 \times \mathrm{xAD}$ in this paper) and littermate $\mathrm{GluN1} 1^{\mathrm{fl} / \mathrm{fl}}$ and GluN2B $\mathrm{B}^{\mathrm{fl} / \mathrm{fl}}$ mice (termed $\mathrm{WT}$ in this paper).

\subsection{Stereotactic Injection of $r A A V s$}

rAAVs were produced as previously described [46]. The following rAAVs were stereotactically injected trough a thin glass capillary into the somatosensory cortex (anteroposterior, $-2.5 \mathrm{~mm}$; mediolateral, $+3.5 \mathrm{~mm}$; dorsoventral, $-0.5 \mathrm{~mm}$ according to Bregma): rAAV-CaMKII-tdTom (control cells), rAAV-CaMKII-CT100(I716F)-T2A-tdTom (for CT100(I716F)-overexpression), rAAV-Syn-Cre-T2A-GFP (for NMDAR subunit deletion), and rAAV-Syn-Cre-T2A-GFP + rAAV-CaMKII-CT100(I716F)-T2A-tdTom (for NMDAR subunit deletion and CT100(I716F)-overexpression).

\subsection{Preparation of Acute Slices}

Ice-cold slicing solution ( $212 \mathrm{mM}$ sucrose, $26 \mathrm{mM} \mathrm{NaHCO}_{3}, 1.25 \mathrm{mM} \mathrm{NaH}_{2} \mathrm{PO}_{4}, 3 \mathrm{mM}$ $\mathrm{KCl}, 0.2 \mathrm{mM} \mathrm{CaCl}_{2}, 7 \mathrm{mM} \mathrm{MgCl}_{2}$, and $10 \mathrm{mM}$ glucose) was trans-cardially perfused in deeply anesthetized mice ( $3 \%$ isoflurane). Whole mouse brains were carefully extracted and cut into $250-\mu \mathrm{m}$-thick coronal mouse brain slices submerged in slicing solution with the help of a tissue slicer (VT1200 S, Leica, Wetzlar, Germany).

Acute slices were stored in a holding chamber filled with $37^{\circ} \mathrm{C}$ artificial cerebral spine fluid (ACSF: $125 \mathrm{mM} \mathrm{NaCl}, 25 \mathrm{mM} \mathrm{NaHCO}_{3}, 1.25 \mathrm{mM} \mathrm{NaH}_{2} \mathrm{PO}_{4}, 2.5 \mathrm{mM} \mathrm{KCl}, 2 \mathrm{mM} \mathrm{CaCl}$, $1 \mathrm{mM} \mathrm{MgCl}_{2}$, and $25 \mathrm{mM}$ glucose) for $15 \mathrm{~min}$ and subsequently cooled down to RT. Slices were used for electrophysiological recordings no earlier than $1 \mathrm{~h}$ after slice preparation.

\subsection{Electrophysiology}

Slices were fully submerged and continuously perfused $(1 \mathrm{~mL} / \mathrm{min})$ with carbogensaturated ACSF at RT. Slices were viewed with an Olympus BX51WI upright microscope (Olympus, Shinjuku, Japan) fitted with a $4 \mathrm{x}$ air (Plan N, NA 0.1; Olympus, Shinjuku, Japan) and 40x water-immersion (LUMPlan FI/IR, NA $0.8 \mathrm{w}$; Olympus, Shinjuku, Japan) objective and imaged with a CCD camera (XM10R, Olympus, Shinjuku, Japan).

Electrical signals were acquired at $10 \mathrm{kHz}$ for mEPSC recordings and $50 \mathrm{kHz}$ for all other recordings using an EPC10 amplifier (HEKA, Reutlingen, Germany), connected to a probe and PC. Electrical signals were recorded with the help of Patchmaster software (HEKA, Germany). Liquid junction potential was not adjusted. Ten micrometers of SR95531 hydrobromide (Biotrend, Germany) were added to the ACSF for all recordings. For mEPSC recordings, $1 \mu \mathrm{M}$ TTX (Biotrend, Cologne, Germany) and $50 \mu \mathrm{M}$ APV (Biotrend, Cologne, 
Germany) were added to the ACSF. For the analysis of NMDAR decays, $50 \mu \mathrm{M}$ CNQX (Biotrend, Cologne, Germany) and $10 \mu \mathrm{M}$ SR95531 hydrobromide (Biotrend, Cologne, Germany) were added to the ACSF.

Extracellular stimulation of pyramidal cells in layer 5 of the somatosensory cortex was performed by placing a stimulation electrode (chlorinated silver wire inside a borosilicate glass capillary filled with ACSF) in layer VI in close proximity to the patched neuron. The stimulus was generated by a stimulus isolator (WPI, Sarasota, FL, USA) connected with the EPC10 amplifier, which was connected to the stimulation pipette and the output was triggered by the Patchmaster software (version v2x90).

Extrasynaptic NMDARs were analyzed as described previously [107]. Briefly, nucleated patches were pulled from pyramidal cells in the somatosensory of acute brain slices. Patches were placed in front of a theta glass mounted onto a piezo translator (PI, Karlsruhe, Germany) that allowed the application of $1 \mathrm{mM}$ glutamate for $1 \mathrm{~ms}$. Application pipettes were tested by perfusing solutions with different salt concentrations through the two barrels onto open patch pipettes and recording current changes with 1 and $100 \mathrm{~ms}$ transitions of the application pipette. Only application pipettes with $20-80 \%$ rise times below $120 \mu$ s and with a reasonable symmetrical on- and offset were used. The application solution contained (in $\mathrm{mM}$ ): $135 \mathrm{NaCl}, 10 \mathrm{HEPES}, 5.4 \mathrm{KCl}, 1.8 \mathrm{CaCl}_{2}, 5$ glucose, $0.01 \mathrm{CNQX}$, and 0.01 glycine ( $\mathrm{pH} 7.2)$ without and without $1 \mathrm{mM}$ glutamate.

\subsection{Morphological Analysis}

Pyramidal cells of the somatosensory cortex were filled with an intracellular solution (see above) containing $0.1-0.5 \%$ biocytin (Sigma Aldrich, St. Louis, MO, USA) through the patch-pipette during electrophysiological recordings. Subsequently, slices were fixed in $4 \%$ Histofix solution (Carl Roth, Karlsruhe, Germany) for several days, washed in 1xPBS (phosphate buffered saline) and permeabilized in $0.2 \%$ PBS-T (1xPBS with $0.2 \%$ Triton). A Streptavidin-coupled fluorescent dye (Alexa Fluor ${ }^{\mathrm{TM}} 594$ streptavidin, life technologies, Carlsbad, CA, USA) was incubated overnight at a dilution of 1:1000, in order to bind to biocytin. Acute slices obtained from 5xFAD and WT mice were additionally stained with an Alexa488-coupled 6E10 Antibody (Covance, New Jersey, DE, USA) at a dilution of 1:400 for A $\beta$ staining. After washing in 1xPBS, slices were mounted in ProLong Gold Antifade (life technologies, USA). Z-stacks of selected dendrites of pyramidal cells were imaged with a fixed-stage Leica TCS SP5 II microscope (Leica, Germany) and the Leica LAS AF Lite Software (Leica, Wetzlar, Germany) with a 63x oil-immersion objective (Leica, Germany) with the following parameters: voxel size $x / y=0.08 \mu \mathrm{m}, z=0.168 \mu \mathrm{m}$. Dendritic spines were counted semi-automatically with the help of Neuronstudio (CNIC, Mount Sinai School of Medicine, USA). Amira (Thermo Fisher Scientific, Waltham, MA, USA) was used for blind deconvolution to improve image quality for spine analysis.

\subsection{Analysis and Statistics}

mEPSCs were analyzed with a template matching algorithm using the mini-analysis plugin of the Clampfit software (Molecular Devices, San José, CA, USA). Intrinsic electrophysiological properties, firing pattern analysis, as well as decay and deactivation analyses were performed with IGOR Pro (WaveMetrix, Lake Oswego, OR, USA) containing the Patcher's Power Tools and Neuromatic analysis package (MPI for biophysical chemistry, Germany and Jason Rothman [108]). The weighted decay and deactivation time constants were calculated as $\tau \mathrm{w}=(\tau \mathrm{f} x \mathrm{af})+(\tau \mathrm{s} x \mathrm{as})$, where af and as are the relative amplitudes of the fast $(\tau \mathrm{f})$ and slow $(\tau \mathrm{s})$ exponential components.

Microsoft Office Excel (Microsoft, USA) and GraphPad Prism (GraphPad 6 software, San Diego, CA, USA) were used for data processing and statistical calculations. Datasets were tested for statistical significance with t-test (for normally distributed data), MannWhitney (MW; for not-normally distributed data) or Kruskal-Wallis (followed by Dunn's posttest) tests. Data are shown as median \pm interquartile ranges (IQR). $p$ values $<0.05$ were 
considered statistically significant $\left({ }^{*}=p<0.05,{ }^{* *}=p<0.01,{ }^{* * *}=p<0.001\right)$. All figures were prepared with Adobe Illustrator CS5.5 (Adobe, Mountain View, CA, USA).

Supplementary Materials: The following are available online at https:/ /www.mdpi.com/article/10 $.3390 /$ ijms22126298/s1.

Author Contributions: M.K.B., E.J. and S.R. performed the measurements, M.K.B. and J.v.E. were involved in planning and supervised the work, M.K.B., E.J. and S.R. processed the experimental data and performed the analysis. M.K.B. designed the figures. M.K.B. and J.v.E. drafted the manuscript and interpreted the results. All authors have read and agreed to the published version of the manuscript.

Funding: This research was funded by the Fritz Thyssen foundation (Az. 10.15.1.017MN; approval date: 6 July 2017).

Institutional Review Board Statement: The study was conducted according to the guidelines of the Declaration of Helsinki, and approved by the state investigation office of Rhineland Palatinate and Baden-Wuerttemberg (G65/12; 23 May 2012).

Informed Consent Statement: Not applicable.

Data Availability Statement: The data presented in this study are available on request from the corresponding author.

Acknowledgments: We thank Barbara Biesalski for technical help.

Conflicts of Interest: The authors declare no conflict of interest.

\section{References}

1. Näslund, J.; Haroutunian, V.; Mohs, R.C.; Davis, K.L.; Davies, P.; Greengard, P.; Buxbaum, J. Correlation Between Elevated Levels of Amyloid $\beta$-Peptide in the Brain and Cognitive Decline. JAMA 2000, 283, 1571-1577. [CrossRef]

2. Thal, D.R.; Rüb, U.; Orantes, M.; Braak, H. Phases of A $\beta$-deposition in the human brain and its relevance for the development of AD. Neurology 2002, 58, 1791-1800. [CrossRef] [PubMed]

3. Whitesell, J.D.; Buckley, A.R.; Knox, J.E.; Kuan, L.; Graddis, N.; Pelos, A.; Mukora, A.; Wakeman, W.; Bohn, P.; Ho, A.; et al. Whole brain imaging reveals distinct spatial patterns of amyloid beta deposition in three mouse models of Alzheimer's disease. J. Comp. Neurol. 2019, 527, 2122-2145. [CrossRef]

4. Braak, H.; Braak, E. Neuropathological stageing of Alzheimer-related changes. Acta Neuropathol. 1991, 82, 239-259. [CrossRef] [PubMed]

5. Pimplikar, S.W. Reassessing the amyloid cascade hypothesis of Alzheimer's disease. Int. J. Biochem. Cell Biol. 2009, 41, 1261-1268. [CrossRef]

6. Koychev, I.; Hofer, M.; Friedman, N.C. Correlation of Alzheimer Disease Neuropathologic Staging with Amyloid and Tau Scintigraphic Imaging Biomarkers. J. Nucl. Med. 2020, 61, 1413-1418. [CrossRef] [PubMed]

7. Crowe, S.E.; Ellis-Davies, G.C.R. Spine pruning in 5xFAD mice starts on basal dendrites of layer 5 pyramidal neurons. Brain Struct. Funct. 2013, 219, 571-580. [CrossRef]

8. Winblad, B.; Poritis, N. Memantine in severe dementia: Results of the 9M-best study (benefit and efficacy in severly demented patients during treatment with memantine). Int. J. Geriatr. Psychiatry 1999, 14, 135-146. [CrossRef]

9. Reisberg, B.; Doody, R.; Stöffler, A.; Schmitt, F.; Ferris, S.; Möbius, H.J. Memantine in Moderate-to-Severe Alzheimer's Disease. N. Engl. J. Med. 2003, 348, 1333-1341. [CrossRef]

10. Hsia, A.Y.; Masliah, E.; McConlogue, L.; Yu, G.-Q.; Tatsuno, G.; Hu, K.; Kholodenko, D.; Malenka, R.C.; Nicoll, R.A.; Mucke, L. Plaque-independent disruption of neural circuits in Alzheimer's disease mouse models. Proc. Natl. Acad. Sci. USA 1999, 96, 3228-3233. [CrossRef] [PubMed]

11. Kamenetz, F.; Tomita, T.; Hsieh, H.; Seabrook, G.; Borchelt, D.; Iwatsubo, T.; Sisodia, S.; Malinow, R. APP Processing and Synaptic Function. Neuron 2003, 37, 925-937. [CrossRef]

12. Snyder, E.M.; Nong, Y.; Almeida, C.G.; Paul, S.; Moran, T.; Choi, E.Y.; Nairn, A.; Salter, M.W.; Lombroso, P.J.; Gouras, G.; et al. Regulation of NMDA receptor trafficking by amyloid- $\beta$. Nat. Neurosci. 2005, 8, 1051-1058. [CrossRef] [PubMed]

13. Kessels, H.; Nabavi, S.; Malinow, R. Metabotropic NMDA receptor function is required for -amyloid-induced synaptic depression. Proc. Natl. Acad. Sci. USA 2013, 110, 4033-4038. [CrossRef]

14. Hsieh, H.; Boehm, J.; Sato, C.; Iwatsubo, T.; Tomita, T.; Sisodia, S.; Malinow, R. AMPAR Removal Underlies A $\beta$-Induced Synaptic Depression and Dendritic Spine Loss. Neuron 2006, 52, 831-843. [CrossRef]

15. Shankar, G.M.; Bloodgood, B.; Townsend, M.; Walsh, D.M.; Selkoe, D.J.; Sabatini, B.L. Natural Oligomers of the Alzheimer Amyloid- $\beta$ Protein Induce Reversible Synapse Loss by Modulating an NMDA-Type Glutamate Receptor-Dependent Signaling Pathway. J. Neurosci. 2007, 27, 2866-2875. [CrossRef] 
16. Calabrese, B.; Shaked, G.M.; Tabarean, I.V.; Braga, J.; Koo, E.H.; Halpain, S. Rapid, concurrent alterations in pre- and postsynaptic structure induced by naturally-secreted amyloid- $\beta$ protein. Mol. Cell. Neurosci. 2007, 35, 183-193. [CrossRef] [PubMed]

17. Hu, N.-W.; Klyubin, I.; Anwyl, R.; Rowan, M.J. GluN2B subunit-containing NMDA receptor antagonists prevent A $\beta$-mediated synaptic plasticity disruption in vivo. Proc. Natl. Acad. Sci. USA 2009, 106, 20504-20509. [CrossRef] [PubMed]

18. Rammes, G.; Hasenjäger, A.; Sroka-Saidi, K.; Deussing, J.; Parsons, C.G. Therapeutic significance of NR2B-containing NMDA receptors and mGluR5 metabotropic glutamate receptors in mediating the synaptotoxic effects of $\beta$-amyloid oligomers on long-term potentiation (LTP) in murine hippocampal slices. Neuropharmacology 2011, 60, 982-990. [CrossRef] [PubMed]

19. Rammes, G.; Mattusch, C.; Wulff, M.; Seeser, F.; Kreuzer, M.; Zhu, K.; Deussing, J.M.; Herms, J.; Parsons, C.G. Involvement of GluN2B subunit containing N-methyl- $\mathrm{d}$-aspartate (NMDA) receptors in mediating the acute and chronic synaptotoxic effects of oligomeric amyloid-beta (A $\beta$ ) in murine models of Alzheimer's disease (AD). Neuropharmacology 2017, 123, 100-115. [CrossRef]

20. Rammes, G.; Seeser, F.; Mattusch, K.; Zhu, K.; Haas, L.; Kummer, M.; Heneka, M.; Herms, J.; Parsons, C.G. The NMDA receptor antagonist Radiprodil reverses the synaptotoxic effects of different amyloid-beta (A $\beta$ ) species on long-term potentiation (LTP). Neuropharmacology 2018, 140, 184-192. [CrossRef]

21. Rönicke, R.; Mikhaylova, M.; Rönicke, S.; Meinhardt, J.; Schröder, U.H.; Fändrich, M.; Reiser, G.; Kreutz, M.R.; Reymann, K.G. Early neuronal dysfunction by amyloid $\beta$ oligomers depends on activation of NR2B-containing NMDA receptors. Neurobiol. Aging 2011, 32, 2219-2228. [CrossRef]

22. Gambrill, A.C.; Barria, A. NMDA receptor subunit composition controls synaptogenesis and synapse stabilization. Proc. Natl. Acad. Sci. USA 2011, 108, 5855-5860. [CrossRef] [PubMed]

23. Kutsuwada, T.; Kashiwabuchi, N.; Mori, H.; Sakimura, K.; Kushiya, E.; Araki, K.; Meguro, H.; Masaki, H.; Kumanishi, T.; Arakawa, M.; et al. Molecular diversity of the NMDA receptor channel. Nature 1992, 358, 36-41. [CrossRef] [PubMed]

24. Monyer, H.; Sprengel, R.; Schoepfer, R.; Herb, A.; Higuchi, M.; Lomeli, H.; Burnashev, N.; Sakmann, B.; Seeburg, P.H. Heteromeric NMDA Receptors: Molecular and Functional Distinction of Subtypes. Science 1992, 256, 1217-1221. [CrossRef]

25. Chazot, P.L.; Stephenson, F.A. Molecular dissection of native mammalian forebrain NMDA receptors containing the NR1 C2 exon Direct demonstration of NMDA receptors comprising NR1, NR2A, and NR2B subunits within the same complex. J. Neurochem. 2002, 69, 2138-2144. [CrossRef]

26. Rauner, C.; Köhr, G. Triheteromeric NR1/NR2A/NR2B Receptors Constitute the Major N-Methyl-d-aspartate Receptor Population in Adult Hippocampal Synapses. J. Biol. Chem. 2011, 286, 7558-7566. [CrossRef]

27. Paoletti, P.; Bellone, C.; Zhou, Q. NMDA receptor subunit diversity: Impact on receptor properties, synaptic plasticity and disease. Nat. Rev. Neurosci. 2013, 14, 383-400. [CrossRef]

28. Gascón, S.; Sobrado, M.; Roda, J.M.; Rodríguez-Peña, Á.; Díaz-Guerra, M. Excitotoxicity and focal cerebral ischemia induce truncation of the NR2A and NR2B subunits of the NMDA receptor and cleavage of the scaffolding protein PSD-95. Mol. Psychiatry 2007, 13, 99-114. [CrossRef] [PubMed]

29. Von Engelhardt, J.; Bocklisch, C.; Tönges, L.; Herb, A.; Mishina, M.; Monyer, H. GluN2D-containing NMDA receptors-mediate synaptic currents in hippocampal interneurons and pyramidal cells in juvenile mice. Front. Cell. Neurosci. 2015, 9, 95. [CrossRef]

30. Luo, J.; Wang, Y.; Yasuda, R.P.; Dunah, A.W.; Wolfe, B.B. The Majority of N-Methyl-d-Aspartate Receptor Complexes in Adult Rat Cerebral Cortex Contain at Least Three Different Subunits (NR1/NR2A/NR2B). Mol. Pharmacol. 1997, 51, 79-86. [CrossRef]

31. Tovar, K.R.; McGinley, M.J.; Westbrook, G.L. Triheteromeric NMDA Receptors at Hippocampal Synapses. J. Neurosci. 2013, 33, 9150-9160. [CrossRef] [PubMed]

32. Vicini, S.; Wang, J.F.; Li, J.H.; Zhu, W.J.; Wang, Y.H.; Luo, J.H.; Wolfe, B.B.; Grayson, D.R. Functional and pharmacological differences between recombinant N-methyl-D-aspartate receptors. J. Neurophysiol. 1998, 79, 555-566. [CrossRef]

33. Cull-Candy, S.; Brickley, S.; Farrant, M. NMDA receptor subunits: Diversity, development and disease. Curr. Opin. Neurobiol. 2001, 11, 327-335. [CrossRef]

34. Ferreira, I.; Bajouco, L.; Mota, S.; Auberson, Y.; Oliveira, C.; Rego, A. Amyloid beta peptide 1-42 disturbs intracellular calcium homeostasis through activation of GluN2B-containing N-methyl-d-aspartate receptors in cortical cultures. Cell Calcium 2012, 51, 95-106. [CrossRef]

35. Monyer, H.; Burnashev, N.; Laurie, D.J.; Sakmann, B.; Seeburg, P.H. Developmental and regional expression in the rat brain and functional properties of four NMDA receptors. Neuron 1994, 12, 529-540. [CrossRef]

36. Von Engelhardt, J.; Doganci, B.; Seeburg, P.H.; Monyer, H. Synaptic NR2A-but not NR2B-containing NMDA receptors increase with blockade of ionotropic glutamate receptors. Front. Mol. Neurosci. 2009, 2, 19. [CrossRef]

37. Parsons, M.P.; Raymond, L.A. Extrasynaptic NMDA Receptor Involvement in Central Nervous System Disorders. Neuron 2014, 82, 279-293. [CrossRef] [PubMed]

38. Demuro, A.; Mina, E.; Kayed, R.; Milton, S.C.; Parker, I.; Glabe, C.G. Calcium Dysregulation and Membrane Disruption as a Ubiquitous Neurotoxic Mechanism of Soluble Amyloid Oligomers. J. Biol. Chem. 2005, 280, 17294-17300. [CrossRef] [PubMed]

39. Matos, M.; Augusto, E.; Oliveira, C.; Agostinho, P. Amyloid-beta peptide decreases glutamate uptake in cultured astrocytes: Involvement of oxidative stress and mitogen-activated protein kinase cascades. Neuroscience 2008, 156, 898-910. [CrossRef] [PubMed]

40. Li, S.; Hong, S.; Shepardson, N.E.; Walsh, D.M.; Shankar, G.M.; Selkoe, D. Soluble Oligomers of Amyloid $\beta$ Protein Facilitate Hippocampal Long-Term Depression by Disrupting Neuronal Glutamate Uptake. Neuron 2009, 62, 788-801. [CrossRef] 
41. Hynd, M.R.; Scott, H.L.; Dodd, P.R. Glutamate ${ }_{\text {NMDA }}$ receptor NR1 subunit mRNA expression in Alzheimer's disease. J. Neurochem. 2001, 78, 175-182. [CrossRef]

42. Milnerwood, A.J.; Gladding, C.M.; Pouladi, M.A.; Kaufman, A.M.; Hines, R.M.; Boyd, J.D.; Ko, R.W.; Vasuta, O.C.; Graham, R.K.; Hayden, M.; et al. Early Increase in Extrasynaptic NMDA Receptor Signaling and Expression Contributes to Phenotype Onset in Huntington's Disease Mice. Neuron 2010, 65, 178-190. [CrossRef]

43. Hardingham, G.; Fukunaga, Y.; Bading, H. Extrasynaptic NMDARs oppose synaptic NMDARs by triggering CREB shut-off and cell death pathways. Nat. Neurosci. 2002, 5, 405-414. [CrossRef] [PubMed]

44. Léveillé, F.; El Gaamouch, F.; Gouix, E.; Lecocq, M.; Lobner, D.; Nicole, O.; Buisson, A. Neuronal viability is controlled by a functional relation between synaptic and extrasynaptic NMDA receptors. FASEB J. 2008, 22, 4258-4271. [CrossRef] [PubMed]

45. Zhou, X.; Hollern, D.; Liao, J.; Andrechek, E.; Wang, H. NMDA receptor-mediated excitotoxicity depends on the coactivation of synaptic and extrasynaptic receptors. Cell Death Dis. 2013, 4, e560. [CrossRef] [PubMed]

46. Müller, M.K.; Jacobi, E.; Sakimura, K.; Malinow, R.; Von Engelhardt, J. NMDA receptors mediate synaptic depression, but not spine loss in the dentate gyrus of adult amyloid Beta $(\mathrm{A} \beta)$ overexpressing mice. Acta Neuropathol. Commun. 2018, 6, 110. [CrossRef]

47. Oakley, H.; Cole, S.L.; Logan, S.; Maus, E.; Shao, P.; Craft, J.; Guillozet-Bongaarts, A.; Ohno, M.; Disterhoft, J.; Van Eldik, L.; et al. Intraneuronal beta-Amyloid Aggregates, Neurodegeneration, and Neuron Loss in Transgenic Mice with Five Familial Alzheimer's Disease Mutations: Potential Factors in Amyloid Plaque Formation. J. Neurosci. 2006, 26, 10129-10140. [CrossRef]

48. Wang, R.; Reddy, P.H. Role of Glutamate and NMDA Receptors in Alzheimer's Disease. J. Alzheimer's Dis. 2017, 57, 1041-1048. [CrossRef]

49. Hardingham, G.E.; Bading, H. Synaptic versus extrasynaptic NMDA receptor signalling: Implications for neurodegenerative disorders. Nat. Rev. Neurosci. 2010, 11, 682-696. [CrossRef] [PubMed]

50. Von Engelhardt, J.; Coserea, I.; Pawlak, V.; Fuchs, E.C.; Köhr, G.; Seeburg, P.H.; Monyer, H. Excitotoxicity in vitro by NR2A- and NR2B-containing NMDA receptors. Neuropharmacology 2007, 53, 10-17. [CrossRef]

51. Sattler, R.; Xiong, Z.; Lu, W.-Y.; Macdonald, J.F.; Tymianski, M. Distinct Roles of Synaptic and Extrasynaptic NMDA Receptors in Excitotoxicity. J. Neurosci. 2000, 20, 22-33. [CrossRef]

52. Papouin, T.; Ladépêche, L.; Ruel, J.; Sacchi, S.; Labasque, M.; Hanini, M.; Groc, L.; Pollegioni, L.; Mothet, J.-P.; Oliet, S.H. Synaptic and Extrasynaptic NMDA Receptors Are Gated by Different Endogenous Coagonists. Cell 2012, 150, 633-646. [CrossRef] [PubMed]

53. Wroge, C.M.; Hogins, J.; Eisenman, L.; Mennerick, S. Synaptic NMDA Receptors Mediate Hypoxic Excitotoxic Death. J. Neurosci. 2012, 32, 6732-6742. [CrossRef] [PubMed]

54. Zhou, X.; Ding, Q.; Chen, Z.; Yun, H.; Wang, H. Involvement of the GluN2A and GluN2B Subunits in Synaptic and Extrasynaptic N-methyl-d-aspartate Receptor Function and Neuronal Excitotoxicity. J. Biol. Chem. 2013, 288, 24151-24159. [CrossRef]

55. Hansen, K.B.; Ogden, K.K.; Yuan, H.; Traynelis, S.F. Distinct functional and pharmacological properties of Triheteromeric GluN1/GluN2A/GluN2B NMDA receptors. Neuron 2014, 81, 1084-1096. [CrossRef]

56. Queenan, B.N.; Lee, K.J.; Pak, D.T.S. Wherefore Art Thou, Homeo(stasis)? Functional Diversity in Homeostatic Synaptic Plasticity. Neural Plast. 2012, 2012, 718203. [CrossRef]

57. Brown, J.T.; Chin, J.; Leiser, S.C.; Pangalos, M.N.; Randall, A.D. Altered intrinsic neuronal excitability and reduced Na+ currents in a mouse model of Alzheimer's disease. Neurobiol. Aging 2011, 32, 2109.e1-2109.e14. [CrossRef]

58. Kerrigan, T.; Brown, J.T.; Randall, A. Characterization of altered intrinsic excitability in hippocampal CA1 pyramidal cells of the A $\beta$-overproducing PDAPP mouse. Neuropharmacology 2014, 79, 515-524. [CrossRef]

59. Tamagnini, F.; Scullion, S.; Brown, J.T.; Randall, A.D. Intrinsic excitability changes induced by acute treatment of hippocampal CA1 pyramidal neurons with exogenous amyloid $\beta$ peptide. Hippocampus 2015, 25, 786-797. [CrossRef]

60. Born, H. Seizures in Alzheimer's disease. Neuroscience 2015, 286, 251-263. [CrossRef] [PubMed]

61. Gray, J.A.; Shi, Y.; Usui, H.; During, M.J.; Sakimura, K.; Nicoll, R.A. Distinct Modes of AMPA Receptor Suppression at Developing Synapses by GluN2A and GluN2B: Single-Cell NMDA Receptor Subunit Deletion In Vivo. Neuron 2011, 71, 1085-1101. [CrossRef]

62. Guardia-Laguarta, C.; Pera, M.; Clarimón, J.; Molinuevo, J.L.; Sànchez-Valle, R.; Lladó, A.; Coma, M.; Gómez-Isla, T.; Blesa, R.; Ferrer, I.; et al. Clinical, Neuropathologic, and Biochemical Profile of the Amyloid Precursor Protein I716F Mutation. J. Neuropathol. Exp. Neurol. 2010, 69, 53-59. [CrossRef] [PubMed]

63. Crouzin, N.; Baranger, K.; Cavalier, M.; Marchalant, Y.; Cohen-Solal, C.; Roman, F.S.; Khrestchatisky, M.; Rivera, S.; Féron, F.; Vignes, M. Area-Specific Alterations of Synaptic Plasticity in the 5XFAD Mouse Model of Alzheimer's Disease: Dissociation between Somatosensory Cortex and Hippocampus. PLoS ONE 2013, 8, e74667. [CrossRef] [PubMed]

64. Li, S.; Jin, M.; Koeglsperger, T.; Shepardson, N.E.; Shankar, G.M.; Selkoe, D.J. Soluble A $\beta$ Oligomers Inhibit Long-Term Potentiation through a Mechanism Involving Excessive Activation of Extrasynaptic NR2B-Containing NMDA Receptors. J. Neurosci. 2011, 31, 6627-6638. [CrossRef]

65. Sun, W.; Hansen, K.B.; Jahr, C.E. Allosteric Interactions between NMDA Receptor Subunits Shape the Developmental Shift in Channel Properties. Neuron 2017, 94, 58-64.e3. [CrossRef]

66. Okamoto, S.-I.; Pouladi, M.A.; Talantova, M.; Yao, D.; Xia, P.; Ehrnhoefer, D.E.; Zaidi, R.; Clemente, A.; Kaul, M.; Graham, R.K.; et al. Balance between synaptic versus extrasynaptic NMDA receptor activity influences inclusions and neurotoxicity of mutant huntingtin. Nat. Med. 2009, 15, 1407-1413. [CrossRef] [PubMed] 
67. Hollmann, M.; Boulter, J.; Maron, C.; Beasley, L.; Sullivan, J.; Pecht, G.; Heinemann, S. Zinc potentiates agonist-induced currents at certain splice variants of the NMDA receptor. Neuron 1993, 10, 943-954. [CrossRef]

68. Traynelis, S.; Hartley, M.; Heinemann, S. Control of proton sensitivity of the NMDA receptor by RNA splicing and polyamines. Science 1995, 268, 873-876. [CrossRef]

69. Traynelis, S.F.; Burgess, M.F.; Zheng, F.; Lyuboslavsky, P.; Powers, J.L. Control of Voltage-Independent Zinc Inhibition of NMDA Receptors by the NR1 Subunit. J. Neurosci. 1998, 18, 6163-6175. [CrossRef]

70. Rumbaugh, G.; Prybylowski, K.; Wang, J.F.; Vicini, S. Exon 5 and spermine regulate deactivation of NMDA receptor subtypes. J. Neurophysiol. 2000, 83, 1300-1306. [CrossRef]

71. Laurie, D.J.; Seeburg, P.H. Regional and developmental heterogeneity in splicing of the rat brain NMDAR1 mRNA. J. Neurosci. 1994, 14, 3180-3194. [CrossRef]

72. Standaert, D.G.; Testa, C.M.; Penney, J.B.; Young, A.B. Alternatively spliced isoforms of the NMDAR1 glutamate receptor subunit: Differential expression in the basal ganglia of the rat. Neurosci. Lett. 1993, 152, 161-164. [CrossRef]

73. Standaert, D.; Testa, C.M.; Young, A.B.; Penney, J.B. Organization of N-methyl-D-aspartate glutamate receptor gene expression in the basal ganglia of the rat. J. Comp. Neurol. 1994, 343, 1-16. [CrossRef]

74. Paupard, M.-C.; Friedman, L.; Zukin, R. Developmental regulation and cell-specific expression of N-methyl-d-aspartate receptor splice variants in rat hippocampus. Neuroscience 1997, 79, 399-409. [CrossRef]

75. Zhong, J.; Carrozza, D.P.; Williams, K.; Pritchett, D.B.; Molinoff, P.B. Expression of mRNAs Encoding Subunits of the NMDA Receptor in Developing Rat Brain. J. Neurochem. 2002, 64, 531-539. [CrossRef]

76. Lee, K.; Moussa, C.; Lee, Y.; Sung, Y.; Howell, B.; Turner, R.; Pak, D.; Hoe, H. Beta amyloid-independent role of amyloid precursor protein in generation and maintenance of dendritic spines. Neuroscience 2010, 169, 344-356. [CrossRef] [PubMed]

77. Hsiao, K.; Chapman, P.; Nilsen, S.; Eckman, C.; Harigaya, Y.; Younkin, S.; Yang, F.; Cole, G. Correlative Memory Deficits, Abeta Elevation, and Amyloid Plaques in Transgenic Mice. Science 1996, 274, 99-103. [CrossRef]

78. Koistinaho, M.; Ort, M.; Cimadevilla, J.M.; Vondrous, R.; Cordell, B.; Bures, J.; Higgins, L.S. Specific spatial learning deficits become severe with age in $\beta$-amyloid precursor protein transgenic mice that harbor diffuse $\beta$-amyloid deposits but do not form plaques. Proc. Natl. Acad. Sci. USA 2001, 98, 14675-14680. [CrossRef]

79. Preda, S.; Govoni, S.; Lanni, C.; Racchi, M.; Mura, E.; Grilli, M.; Marchi, M. Acute $\beta$-Amyloid Administration Disrupts the Cholinergic Control of Dopamine Release in the Nucleus Accumbens. Neuropsychopharmacology 2007, 33, 1062-1070. [CrossRef]

80. Puzzo, D.; Privitera, L.; Fa', M.; Staniszewski, A.; Hashimoto, G.; Aziz, F.; Sakurai, M.; Ribe, E.M.; Troy, C.M.; Mercken, M.; et al. Endogenous amyloid- $\beta$ is necessary for hippocampal synaptic plasticity and memory. Ann. Neurol. 2010, 69, 819-830. [CrossRef]

81. Puzzo, D.; Privitera, L.; Leznik, E.; Fà, M.; Staniszewski, A.; Palmeri, A.; Arancio, O. Picomolar Amyloid- $\beta$ Positively Modulates Synaptic Plasticity and Memory in Hippocampus. J. Neurosci. 2008, 28, 14537-14545. [CrossRef]

82. Grilli, M.; Lagomarsino, F.; Zappettini, S.; Preda, S.; Mura, E.; Govoni, S.; Marchi, M. Specific inhibitory effect of amyloid- $\beta$ on presynaptic muscarinic receptor subtypes modulating neurotransmitter release in the rat nucleus accumbens. Neuroscience 2010, 167, 482-489. [CrossRef] [PubMed]

83. Pardossi-Piquard, R.; Checler, F. The physiology of the $\beta$-amyloid precursor protein intracellular domain AICD. J. Neurochem. 2011, 120, 109-124. [CrossRef]

84. Montagna, E.; Dorostkar, M.M.; Herms, J. The Role of APP in Structural Spine Plasticity. Front. Mol. Neurosci. 2017, 10, 136. [CrossRef]

85. Müller, T.; Meyer, H.E.; Egensperger, R.; Marcus, K. The amyloid precursor protein intracellular domain (AICD) as modulator of gene expression, apoptosis, and cytoskeletal dynamics-Relevance for Alzheimer's disease. Prog. Neurobiol. 2008, 85, 393-406. [CrossRef] [PubMed]

86. Schettini, G.; Govoni, S.; Racchi, M.; Rodriguez, G. Phosphorylation of APP-CTF-AICD domains and interaction with adaptor proteins: Signal transduction and/or transcriptional role-Relevance for Alzheimer pathology. J. Neurochem. 2010, 115, 1299-1308. [CrossRef] [PubMed]

87. Mehr, A.; Hick, M.; Ludewig, S.; Müller, M.; Herrmann, U.; Von Engelhardt, J.; Wolfer, D.P.; Korte, M.; Müller, U.C. Lack of APP and APLP2 in GABAergic Forebrain Neurons Impairs Synaptic Plasticity and Cognition. Cereb. Cortex 2020, 30, 4044-4063. [CrossRef] [PubMed]

88. Tyan, S.-H.; Shih, A.Y.-J.; Walsh, J.; Maruyama, H.; Sarsoza, F.; Ku, L.; Eggert, S.; Hof, P.R.; Koo, E.H.; Dickstein, D.L. Amyloid precursor protein (APP) regulates synaptic structure and function. Mol. Cell. Neurosci. 2012, 51, 43-52. [CrossRef]

89. Weyer, S.W.; Zagrebelsky, M.; Herrmann, U.; Hick, M.; Ganss, L.; Gobbert, J.; Gruber, M.; Altmann, C.; Korte, M.; Deller, T.; et al. Comparative analysis of single and combined APP/APLP knockouts reveals reduced spine density in APP-KO mice that is prevented by APPs $\alpha$ expression. Acta Neuropathol. Commun. 2014, 2, 36. [CrossRef]

90. Steubler, V.; Erdinger, S.; Back, M.K.; Ludewig, S.; Fässler, D.; Richter, M.; Han, K.; Slomianka, L.; Amrein, I.; von Engelhardt, J.; et al. Loss of all three APP family members during development impairs synaptic function and plasticity, disrupts learning, and causes an autism-like phenotype. EMBO J. 2021, e107471. [CrossRef]

91. Holtmaat, A.J.; Trachtenberg, J.T.; Wilbrecht, L.; Shepherd, G.M.; Zhang, X.; Knott, G.W.; Svoboda, K. Transient and Persistent Dendritic Spines in the Neocortex In Vivo. Neuron 2005, 45, 279-291. [CrossRef]

92. Berry, K.P.; Nedivi, E. Spine Dynamics: Are They All the Same? Neuron 2017, 96, 43-55. [CrossRef] [PubMed] 
93. Grutzendler, J.; Kasthuri, N.; Gan, W.-B. Long-term dendritic spine stability in the adult cortex. Nature 2002, $420,812-816$. [CrossRef] [PubMed]

94. Akashi, K.; Kakizaki, T.; Kamiya, H.; Fukaya, M.; Yamasaki, M.; Abe, M.; Natsume, R.; Watanabe, M.; Sakimura, K. NMDA Receptor GluN2B (GluRe2/NR2B) Subunit Is Crucial for Channel Function, Postsynaptic Macromolecular Organization, and Actin Cytoskeleton at Hippocampal CA3 Synapses. J. Neurosci. 2009, 29, 10869-10882. [CrossRef]

95. Alvarez, V.A.; Ridenour, D.A.; Sabatini, B.L. Distinct Structural and Ionotropic Roles of NMDA Receptors in Controlling Spine and Synapse Stability. J. Neurosci. 2007, 27, 7365-7376. [CrossRef] [PubMed]

96. Papouin, T.; Oliet, S.H.R. Organization, control and function of extrasynaptic NMDA receptors. Philos. Trans. R. Soc. B Biol. Sci. 2014, 369, 20130601. [CrossRef]

97. Papadia, S.; Stevenson, P.; Hardingham, N.R.; Bading, H.; Hardingham, G.E. Nuclear Ca ${ }^{2+}$ and the cAMP Response ElementBinding Protein Family Mediate a Late Phase of Activity-Dependent Neuroprotection. J. Neurosci. 2005, 25, 4279-4287. [CrossRef]

98. Jiang, X.; Tian, F.; Mearow, K.; Okagaki, P.; Lipsky, R. The excitoprotective effect of N-methyl-d-aspartate receptors is mediated by a brain-derived neurotrophic factor autocrine loop in cultured hippocampal neurons. J. Neurochem. 2005, 94, 713-722. [CrossRef]

99. Lau, D.; Bading, H. Synaptic Activity-Mediated Suppression of p53 and Induction of Nuclear Calcium-Regulated Neuroprotective Genes Promote Survival through Inhibition of Mitochondrial Permeability Transition. J. Neurosci. 2009, 29, 4420-4429. [CrossRef]

100. Dieterich, D.C.; Karpova, A.; Mikhaylova, M.; Zdobnova, I.; König, I.; Landwehr, M.; Kreutz, M.; Smalla, K.-H.; Richter, K.; Landgraf, P.; et al. Caldendrin-Jacob: A Protein Liaison That Couples NMDA Receptor Signalling to the Nucleus. PLoS Biol. 2008, 6, e34. [CrossRef] [PubMed]

101. Xu, J.; Kurup, P.; Zhang, Y.; Goebel-Goody, S.M.; Wu, P.H.; Hawasli, A.H.; Baum, M.L.; Bibb, J.A.; Lombroso, P.J. Extrasynaptic NMDA Receptors Couple Preferentially to Excitotoxicity via Calpain-Mediated Cleavage of STEP. J. Neurosci. 2009, 29, 9330-9343. [CrossRef]

102. Zhang, S.-J.; Steijaert, M.N.; Lau, D.; Schütz, G.; Delucinge-Vivier, C.; Descombes, P.; Bading, H. Decoding NMDA Receptor Signaling: Identification of Genomic Programs Specifying Neuronal Survival and Death. Neuron 2007, 53, 549-562. [CrossRef]

103. Voronin, L.L.; Cherubini, E. 'Deaf, mute and whispering' silent synapses: Their role in synaptic plasticity. J. Physiol. 2004, 557, 3-12. [CrossRef]

104. Niewoehner, B.; Single, F.N.; Hvalby, Ø.; Jensen, V.; Borgloh, S.M.Z.A.; Seeburg, P.H.; Rawlins, J.N.P.; Sprengel, R.; Bannerman, D.M. Impaired spatial working memory but spared spatial reference memory following functional loss of NMDA receptors in the dentate gyrus. Eur. J. Neurosci. 2007, 25, 837-846. [CrossRef] [PubMed]

105. Von Engelhardt, J.; Doganci, B.; Jensen, V.; Hvalby, Ø.; Göngrich, C.; Taylor, A.; Barkus, C.; Sanderson, D.J.; Rawlins, J.N.P.; Seeburg, P.H.; et al. Contribution of Hippocampal and Extra-Hippocampal NR2B-Containing NMDA Receptors to Performance on Spatial Learning Tasks. Neuron 2008, 60, 846-860. [CrossRef]

106. Bhattacharya, S.; Haertel, C.; Maelicke, A.; Montag, D. Galantamine Slows Down Plaque Formation and Behavioral Decline in the 5XFAD Mouse Model of Alzheimer's Disease. PLoS ONE 2014, 9, e89454. [CrossRef] [PubMed]

107. Chen, X.; Aslam, M.; Gollisch, T.; Allen, K.; Von Engelhardt, J. CKAMP44 modulates integration of visual inputs in the lateral geniculate nucleus. Nat. Commun. 2018, 9, 261. [CrossRef] [PubMed]

108. Rothman, J.S.; Silver, R.A. NeuroMatic: An Integrated Open-Source Software Toolkit for Acquisition, Analysis and Simulation of Electrophysiological Data. Front. Neuroinform. 2018, 12, 14. [CrossRef] 